\title{
Corpus Analysis of the Collocations of the Transitive Verbs owaru and oeru
}

\author{
Nastja PAHOR \\ University of Ljubljana, Slovenia \\ nastja.pahor@gmail.com
}

\begin{abstract}
The transitivity of Japanese verbs is a topic, which had been widely discussed in Japan even before the beginning of the Meiji period and is still one of the major obstacles for learners of Japanese nowadays. This paper focuses on the transitivity of the verbs owaru 終わる (to end [tr./intr.]) and oeru 終える (to end [tr.]). It encompasses the analysis of collocations of the two verbs and examines their objects in the patterns ' $\mathrm{N}$ wo owaru' and ' $\mathrm{N}$ wo oeru'. The aim of this research is to give a new perspective on the usage of the two verbs. The analysis of both collocations and co-occurring verbal forms shows collocations grouping into individual semantic categories. Furthermore, verbs exhibit specific morphological characteristics in different semantic fields of the collocations.
\end{abstract}

Keywords: verb transitivity; owaru; oeru; collocations; corpus

\section{Povzetek}

Prehodnost japonskih glagolov je tema, o kateri se je na Japonskem široko razpravljalo že pred začetkom obdobja Meiji in še dandanes predstavlja eno večjih ovir pri učenju japonskega jezika. Raziskava se osredotoča na prehodno rabo glagolov owaru 終わる (končati, končati se) in oeru 終える (končati) in podaja analizo njunih kolokacij oziroma predmetov v stavčnem vzorcu ' $N$ wo owaru' in ' $\mathrm{N}$ wo oeru'. Cilj študije je razjasnitev rabe obeh glagolov. Rezultati analize kolokacij in sopojavljajočih glagolskih oblik kažejo na porazdelitev kolokacij v specifična semantična polja ter na obstoj določenih morfoloških lastnostih glagolov, ki se pojavljajo $\mathrm{v}$ različnih semantičnih skupinah kolokacij.

Ključne besede: glagolska prehodnost; owaru; oeru; kolokacije; korpus 


\section{Introduction}

The discussion regarding verb transitivity in Japan can be observed even before the beginning of the Meiji period (Okutsu, 1967, p. 46). To this day, differentiating between transitive and intransitive verbs is still one of the major obstacles for learners of Japanese. Transitive verbs are those that take on an object and intransitive verbs are those that cannot take on an object.

This paper discusses the transitivity of the verbs owaru 終わる (to end, finish [tr./intr.]) and oeru 終える (to end, finish [tr.]). Semantically, the verb owaru comprises both the transitive and intransitive meaning, whereas oeru is only used as a transitive verb. Therefore, despite both verbs holding the meaning of 'end' or 'finish', their usage in terms of transitivity differs. The focal point of this paper is the semantic examination and categorization of their respective collocations in the patterns ' $\mathrm{N}$ wo owaru' and ' $\mathrm{N}$ wo oeru'. ' $N$ ' represents the object of the verb, followed by the accusative case particle wo . Additionally, verbal forms co-occurring with each collocation are examined. This part of the research aims to determine if any specific structural patterns or forms are present in each semantic group.

\subsection{Research motivation and purpose}

The general aim of this research is to give a new perspective on the usage of the verbs owaru and oeru, by focusing on the issue of transitivity and categorization of semantic fields of collocations belonging to each verb.

In Section 2, previous research on the topic of transitivity is examined. Section 2.1 establishes the meanings of 'transitive' and 'intransitive verbs', while Section 2.2 focuses specifically on the verbs owaru and oeru as a pair.

However, despite extensive discussions on the topic, discrepancies can still be observed in dictionary definitions of the verbs (Section 3.1). Similarly, an unbalanced representation of the two verbs in instructional materials (Section 3.3), as well as a consequential non-uniform perception of their usage (Section 3.4), can be seen. An example of diachronic change in verb use is also provided (Section 3.2).

To clarify the abovementioned inconsistencies regarding verb transitivity, this paper examines collocations co-occurring with each verb in order to portray a picture of their semantic distribution and compare the two verbs (Section 5). Furthermore, verb forms of owaru and oeru belonging in each semantic group are also analyzed (Sections 6 and 7). 


\subsection{Methodology}

After an analysis of prior research in Section 2, Section 3 is divided into four segments. The first segment (Section 3.1) is dedicated to the analysis of verb definitions that have been retrieved from eight dictionaries, published over several decades. Secondly, Section 3.2 compares dictionary definitions with sample sentences retrieved from the Corpus of Historical Japanese (Nihongo rekishi kōpasu 日本語歴史コーパス, henceforth $\mathrm{CHJ}$ ). The comprised data consist of over 16 million words, with source texts dating to the eras of Nara, Heian, Kamakura, Muromachi, Edo, and Meiji. This analysis is followed by an examination of instructional materials and the way each of them presents the verbs to their audience (Section 3.3). The last part (Section 3.4) deals with the general public's perception of both verbs and their transitivity. Examples, which indicate a mixed understanding of the verbs, especially in regards to owaru, have been retrieved from sites Yahoo! Chiebukuro 知恵袋 and HiNative.

Following is the empirical part of this research. Firstly, sample sentences were retrieved using the following three corpora created by NINJAL (National Institute for Japanese Language and Linguistics Kokuritsu kokugo kenkyūjo 国立国語研究所):

- Balanced Corpus of Contemporary Written Japanese (Gendai nihongo kakikotoba kinkō kōpasu 現代日本語書き言葉均衡コーパス, henceforth BCCWJ). The data are comprised of 104.3 million words from various texts published between 1976-2005.

- Corpus of Spontaneous Japanese (Nihongo hanashikotoba kōpasu 日本語話 し言葉コーパス, henceforth CSJ). It comprises over 650 hours of recordings, transcribed into approximately 7 million words. The data were recorded between 1999-2001.

- Nagoya University Conversation Corpus (Meidai kaiwa kōpasu 名大会話コー パス, henceforth NUCC). 129 conversation recordings, created between 2001-2003, expand over a span of roughly 100 hours.

The concordancer used to filter sentences is Chünagon. Due to a high number of result sentences BCCWJ, the concordancer NINJAL-LWP, which allows sorting according to the frequency of appearance of each word, was used as well. Subsequently, the results were downloaded as an .xlsx file and all sentences were manually analyzed. Details concerning this part of the research are elaborated in Sections 4.

The semantic analysis of collocations is based on Bunrui Goihyō: zōho kaiteiban (分 類語彙表：増補改訂版, Word List by Semantic Principles, Revised and Enlarged Edition), published by NINJAL in 2003. The list is a collection of words classified and arranged by their meanings. Details regarding the process of classification within this paper are explained in Section 5.

The categorization of verbal forms is provided in detail in Sections 6 and 7. 


\section{Verb transitivity}

The discussion regarding verb transitivity has been an ongoing debate, dating back to the beginning of the Meiji era. Okutsu $(1967$, p. 46) cites several linguists that have already researched this topic. These include Motoori Haruniwa, Gonda Naosuke, Kurokawa Harumura, Ōtsuki Fumihiko, Yamada Yoshio, Mochizuki Seikyō, Nishio Teraya, Sakuma Kanae, and Bernard Bloch. Okutsu himself shares some points of view that Haruniwa, Sakuma, and Bloch proposed. However, he points out that the results discovered up to that point were not sufficient to give clear answers regarding the issue of transitivity and consequently proposes his own categorization.

\subsection{Defining intransitive and transitive verbs}

According to Okutsu's criteria, transitive verbs are those that have an object in the form of a noun followed by the case particle wo. All other verbs are intransitive (Numata, 1989 , p. 196). It is important to differentiate between the particle wo marking an object and the particle wo that is followed by verbs of motion.

Additionally, two verbs have to meet conditions on three separate levels to be recognized as a pair.

Firstly, on a morphological level, two verbs must present the same root. Amano et al. (2013, p. 70) give the verbs aku 開く, 'to open' [intr.], and akeru 開ける, 'to open' [tr.], as an example of verbs which share the root /ak/.

Secondly, from a syntactic point of view, the sentence with a transitive verb gains a subject $A$ followed by the case particle $g a$ が, while the subject of the sentence with an intransitive verb $B$ becomes the object of the transitive verb followed by the case particle wo as seen in figure 1 below (Numata, 1989, p. 197; Amano et al., 2013, p. 70).

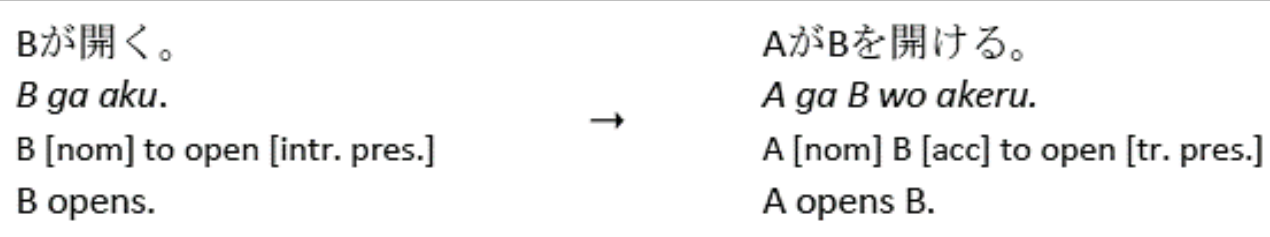

Figure 1: Intransitive verb in relation to its transitive pair

Lastly, a semantic structure must be observed. The subject $A$, which appears in the sentence with a transitive verb, must influence the occurrence or event $B$. Event $B$ takes on the role of an object of the same verb and is simultaneously depicted in the sentence with an intransitive verb as its subject. In short, the sentence with a transitive verb must also cover the meaning of the corresponding intransitive verb sentence. 


\subsection{The verbs owaru and oeru as a pair}

Okutsu $(1967$, p. 63) categorizes the verb oeru as a verb that forms its pair owaru with the process of intransitivization. The shared root verb is 'owe-' (終).

In the section regarding ergative verbs, Morita (1994, p. 240) states that owaru and oeru already exist as a pair. He gives the following sentences as examples:

a) 私は話を終える

Watashi wa hanashi wo oeru.

I [top] story [acc] to finish [tr.act.pres]

I finish the story.

b) 話が終わる

Hanashi ga owaru.

Story [nom] to finish [intr.act.pres]

The story finishes.

Furthermore, Izuhara (2010) responds to a question regarding the nature of owaru in the sentence 'with this I finish the lesson' (kore de jugyō wo owarimasu これで授業 を終わります). With the use of a dictionary definition, according to which owaru is a 'jitadōshi 自他動詞', he explains an ergative verb that allows both transitive and intransitive use.

The most accurate definition of owaru and oeru would be that owaru is a verb that forms two pairs in terms of transitivity. The first one is owaru [intr.] $\rightarrow$ owaru [tr.], whereas the second is owaru [intr.] $\rightarrow$ oeru [tr.].

\subsection{Use of causative}

When an intransitive verb lacks its transitive pair, the role can be performed by the causative form of the intransitive verb. Intransitive verbs that lack a transitive pair are defined as zettai jidōshi 絶対自動詞 (Amano et al., 2013, p. 70). Due to inconsistencies regarding the usage of the verb owaru and the general perception of it being purely intransitive, which are discussed in detail in the following Section 3, I propose the hypothesis that verbs co-occurring with collocations will be found in sentence patterns or phrases including causative forms of the verb owaru. 


\section{Meaning and use of the verbs owaru and oeru}

This section gives an overview of dictionary definitions of both verbs, as well as their representation in instructional materials, and the public's general perception.

\subsection{Use of owaru and oeru according to dictionary definitions}

The verb owaru is categorized as an ergative verb regardless of the dictionary (Table 1). On the other hand, definitions of oeru point at minor inconsistencies in its use. No deviations are found in regards to the transitive use, which is present in all seven dictionaries. However, Kokugo jiten and Daijirin list the intransitive use as well:

Kokugo jiten: 「会期がー・えた」のように、自動的に使うこともある。

'Kaiki ga -- eta' no yō ni, jidōteki ni tsukau koto mo aru.

'The session --' Sometimes used intransitively as shown.

Daijirin：（自動詞）終わる。果てる。

(Jidōshi) Owaru. Hateru.

(Intransitive verb) To end. To finish.

Shin meikai kokugo jiten lists the intransitive use with an annotation of it being based on incorrect use (moto goyō ni motozuku もと誤用に基づく).

Table 1: Dictionary definitions of owaru and oeru

\begin{tabular}{lllll}
\hline \multirow{2}{*}{ Dictionary } & \multicolumn{2}{c}{ owaru } & \multicolumn{2}{c}{ oeru } \\
& intr. use & tr. use & intr. use & tr. use \\
\hline Kōjien 広辞苑, 1955 & YES & YES & NO & YES \\
Kokugo jiten 国語辞典, 1979 & YES & YES & YES & YES \\
$\begin{array}{l}\text { Progressive Japanese-English Dictionary, } \\
\text { 1993 }\end{array}$ & YES & YES & NO & YES \\
$\begin{array}{l}\text { New Japanese-English Dictionary, 1998 } \\
\text { Daijirin 大辞林, 2006 }\end{array}$ & YES & YES & NO & YES \\
jaSlo, 2006 & YES & YES & YES & YES \\
Shin meikai kokugo jiten 新明解国語辞典, & YES & YES & NO & YES \\
2012 & YES & YES & (YES) & YES \\
\hline
\end{tabular}

\subsection{Comparison of the use of owaru and oeru in corpora CHJ and BCCWJ}

A short comparison of the use of verbs owaru and oeru in the Corpus of historical Japanese $\mathrm{CHJ}$ and the Balanced corpus of contemporary written Japanese BCCWJ illustrates some interesting results (see Tables 2 and 3): 
Table 2: Use of owaru and oeru in $\mathrm{CHJ}$

\begin{tabular}{lll}
\hline & owaru & oeru \\
\hline Total cases & 2,178 & 380 \\
Cases of intransitive use $(\mathrm{N}+\mathrm{ga})$ & 64 & 1 \\
Cases of transitive use $(\mathrm{N}+w o)$ & 366 & 227 \\
\hline
\end{tabular}

Table 3: Use of owaru and oeru in BCCWJ

\begin{tabular}{lll}
\hline & owaru & oeru \\
\hline Total cases & 19,244 & 4,624 \\
Cases of intransitive use $(\mathrm{N}+g a)$ & 5,861 & $5(12)$ \\
Cases of transitive use $(\mathrm{N}+w o)$ & 1,046 & 2,921 \\
\hline
\end{tabular}

It is clear that the verb owaru is used more extensively in comparison to oeru. Furthermore, despite some dictionary definitions allowing it, the intransitive use of oeru is negligible, as can be seen in some examples listed below. Out of 12 sentences, only five are actual cases of intransitive use (1-5); others can be explained with the structure indicating volition N1 ga oeyō to suru N2 (6), the potential form oerareru which requires the particle ga が (7), or an incorrect morphological analysis (8-9).

1) つまり、十二年間の修行が終えて仏子戒を受けるのではなくて、[...] Tsumari, jūninenkan no shūgyō ga oete busshikai wo ukeru no de wa nakute, [...] training [nom] to end [intr.act.ger] In brief, as the 12-year-long training finishes, you don't accept the Buddhist principles, [...]

2)このことは、学習会が終えてからいっそう証明されました。 Kono koto wa, gakushūkai ga oete kara issō shōmei saremashita. study group [nom] to finish [intr.act.ger] This became even clearer once the study session finished.

3) やっと三力月が終えようとしていますが、正直ほっとしています。 Yatto sankagetsu ga oeyō to shiteimasu ga, shōjiki hotto shiteimasu. three months [nom] to end [intr.act.vol] Three months have finally come to pass, and I honestly feel relieved.

4）託児が終えたのは十二時頃、[...]

Takuji ga oeta no wa juuniji goro, [...]

daycare [nom] to end [intr.act.pst.adn]

Daycare ended at around 12 o'clock, [...] 
5)『頼政』が終え、『地蔵舞』が演じられるころから、[...]

'Yorimasa' ga oe, 'Jizōmai' ga enjirareru koro kara, [...]

Yorimasa [nom] to finish [intr.act.inf]

Ever since Yorimasa ended and Jizōmai has been performed, [...]

6) おもえば、私たちが終えようとしている今世紀も、なんと、戦争の嵐が 吹き荒れた時代であったことか。

Omoeba, watashitachi ga oeyō to shiteiru konseiki mo, nanto, sensō no arashi ga fukiareta jidai de atta koto $k a$.

we [nom] to end [tr.act.vol]

Come to think of it, has this century, that we are about to end, also been a, what, an era, during which the storm of war blew violently?

7) いずれにせよ、無事取引が終えられるよう、同じ出品者の立場からお祈 りいたしております。

Izure ni seyo, buji torihiki ga oerareru yō, onaji shuppinsha no tachiba kara oinori itashite orimasu.

deal [nom] to end [poten.nonpst.adn]

Either way, as a fellow exhibitor myself, I pray that your deal can be completed without problems.

8) 音大生が卒試で弾くには“技術的には”簡単かもしれません。 Incorrect analysis: 終える・卒える $\rightarrow$ 卒試 (卒業試験)

9) 反抗期をむかえた子どもは手がおえなくなり、親をこまらせる。 Incorrect analysis: 終えない $\rightarrow$ 負えない

Additionally, the diachronic analysis points at a remarkable shift in the usage of owaru. According to results observed in $\mathrm{CHJ}$, the number of cases, in which owaru is used transitively, is approximately six times higher compared to the number of sentences with intransitive use. On the other hand, BCCWJ illustrates a completely reversed picture, as the number of examples of intransitive use is six times higher. This outcome further reinforces the thought that the verb owaru in modern Japanese is heavily leaning towards an exclusively intransitive use.

\subsection{Representation of owaru and oeru in instructional materials}

Owaru is generally represented in its intransitive use when appearing within exercises or texts for reading comprehension. Examples of transitive use are only present in textbook sections dedicated to detailed explanations or glossaries. Similarly, oeru is only mentioned in such sections and does not appear in practical example sentences or other exercises (Table 4). 
Table 4: Representation of owaru and oeru in instructional materials

\begin{tabular}{|c|c|c|c|c|}
\hline \multirow{2}{*}{ Textbook } & \multicolumn{2}{|c|}{ owaru } & \multicolumn{2}{|c|}{ oeru } \\
\hline & intr. use & tr. use & intr. use & tr. use \\
\hline Uvod v japonsko pisavo, 2007 & YES & NO & NO & YES \\
\hline $\begin{array}{l}\text { Japonščina za začetnike } 1 \text { in 2, } \\
\text { 2012/2016* }\end{array}$ & YES & YES & / & / \\
\hline $\begin{array}{l}\text { Minna no nihongo (shokyū 2), } \\
\text { 1998/2013* }\end{array}$ & YES & YES & / & / \\
\hline Kanji Goi ga yowai anata e, 2013* & YES & NO & / & / \\
\hline $\begin{array}{l}\text { Pregled slovnice japonskega jezika, } \\
2005\end{array}$ & YES & YES & NO & YES \\
\hline Tobira, 2009* & YES & NO & / & / \\
\hline Essential Japanese Grammar, 2012 & YES & YES & NO & YES \\
\hline
\end{tabular}

\subsection{General perception of the use of owaru and oeru}

The representation of both verbs in instructional materials mirrors the general perception of the usage of owaru and oeru. Based on various examples taken from the websites Yahoo! Chiebukuro 知恵袋 ${ }^{1}$ and HiNative ${ }^{2}$, the results are consistent with previous findings. Links to full examples are provided in footnotes.

Users express their doubts about the transitive use of owaru and place the two verbs or the particles wo and $g a$ in juxtaposition, questioning the correct use: 'end a lesson' (jugyō wo owaru 授業を終わる and 授業を終える) or 'end a lesson' (jugyō wo owaru 授業を終わる) and 'the lesson ends' (jugyō ga owaru 授業が終わる). It appears that most users lean towards the perception of owaru as solely intransitive.

In response to the above, some answers correctly state that owaru is an ergative verb and point out both the transitive and intransitive use, while others label the transitive use as an exception to the rule, or explain the presence of the particle wo with the causative owaraseru 終わらせる.

Discrepancies in dictionary definitions, a lack of representation in instructional materials and the public's unanimous general perception of both verbs are all points of concern, as well as the main reasons for this research being conducted. Section 4

\footnotetext{
${ }^{1}$ Retrieved from https://detail.chiebukuro.yahoo.co.jp/qa/question detail/q1011595455 https://detail.chiebukuro.yahoo.co.jp/qa/question detail/q12108164892 https://detail.chiebukuro.yahoo.co.jp/qa/question detail/q11114803361 https://detail.chiebukuro.yahoo.co.jp/qa/question detail/q12194686977

${ }^{2}$ Retrieved from https://hinative.com/ja/questions/5638244
} 
The concordancer Chūnagon also allows searching for distant collocations. Such collocations can be found at a distance of at least one or more interposed words (Srdanović, 2016, p. 21). However, due to an already high number of results, the option was set to a fixed distance of one word; the front collocation is immediately followed by the keyword. The option shojikei shutsugenkei 書字形出現形 limits the search to the form of wo as written in the box (を).

On a semantical level, all collocations within examples of corpora CSJ and NUCC were analyzed. A minimal frequency of appearance of 5 for owaru and 15 for oeru was set for collocations found in BCCWJ due to a high number of results. Some additional examples with lower frequency were analyzed for comparison as they appear in both corpora (see Section 5).

On the same basis, verb forms co-occurring with a collocation that represents at least $1 \%$ of all gathered sentences for each verb were analyzed within BCCWJ. For owaru ( 1,046 sentences) this means the analysis of verbs co-occurring with collocations of a frequency of 10 or above; for oeru (2,921 sentences) of 29 or above (see Table 5 below).

Table 5: Number of results in corpora

\begin{tabular}{llllll}
\hline & & BCCWJ & CSJ & NUCC & Total \\
\hline Appearance frequency (general) & owaru & 19,247 & 2,539 & 416 & 22,202 \\
& oeru & 4,624 & 119 & 3 & 4,746 \\
Appearance frequency (transitive) & owaru & 1,046 & 303 & 8 & 1,357 \\
& oeru & 2,921 & 63 & 3 & 2,987 \\
Analyzed verb forms & owaru & 581 & 303 & 8 & 892 \\
& oeru & 623 & 63 & 3 & 689 \\
Analyzed collocations (semantic) & owaru & 640 & 303 & 8 & 951 \\
& oeru & 1,046 & 63 & 3 & 1,112 \\
\hline
\end{tabular}

Due to a low number of sentences in NUCC, the results are grouped with those from CSJ. Both are corpora of spoken Japanese.

Detailed information regarding the semantical and morphological analyses is explained in the upcoming Sections 5, 6, and 7.

\section{Semantical analysis of collocations}

The semantical categorization of collocations (objects of the transitive verbs) is based on Bunrui goihyō: zōho kaiteiban (Word list by semantic principles, revised and enlarged 
edition, henceforth Bunrui goihyō). The word list is comprised of 79,027 lemmas (94,985 words in total). Words in Bunrui goihyō are classified as follows.

Each word is first categorized by 'class', rui 類. This category consists of four groups: 1) nouns - tai no rui 体の類, 2) verbs - yō no rui 用の類, 3) -i and -na adjectives, adverbs and adnominal adjectives - sō no rui 相 $の$ 類, and 4) other - part of adverbs, conjunctions, and interjections - sono ta no rui その他の類.

The categories are then further grouped into 'divisions' (bumon 部門), followed by 'sections' (chūkōmoku 中項目), and finally 'articles' (bunrui kōmoku 分類項目). Each 'article' is then divided into several numbered paragraphs.

For example, the word 'question' (shitsumon 質問) can be found next to the ID number 1.3132, indicating:

- number 1 (1.3132) - class (1. noun, tai no rui 体の類)

- number 3 (1.3132) - division (1.3 human activity - psyche and actions, ningen katsudō - seishin oyobi kōi 人間活動一精神および行為)

- number 1 (1.3132) - section (1.31 language/speech, gengo 言語)

- number 32 (1.3132) - article (1.3132 dialogue, mondō 問答)

All collocations in this paper are classified into semantic groups based on 'sections' (in the example above 'language/speech'), in order to prevent the categorization from becoming too fragmentary and at the same time making a clear distinction between each semantic field.

Tables 6, 7, 9, and 10 provide a list of all collocations with corresponding transcriptions and translations, as well as their frequency of appearance and the semantic field they were sorted into as per the Bunrui goihyō classification.

As mentioned at the end of Section 4, due to a high number of results, restrictions have been applied to collocations and verb forms from BCCWJ. The collocations cooccurring with analyzed verb forms are marked in bold.

\subsection{Owaru}

Collocations of the verb owaru can be classified into nine semantic fields or groups. These are 'time', 'person', 'work', 'speech', 'quantity', 'mental process', 'relationship', 'organization' and 'life' (see Tables 6 and 7). 
Table 6: List of collocations (owaru - BCCWJ)

\begin{tabular}{|c|c|c|c|c|}
\hline \multicolumn{5}{|c|}{ owaru-BCCWJ } \\
\hline Verb object & Transcription & Translation & Frequency & Semantic field \\
\hline 質問 & shitsumon & question & 339 & speech \\
\hline 執行 & shikkō & execution & 78 & work \\
\hline 討論 & tōron & discussion & 37 & speech \\
\hline 仕事 & shigoto & work & 28 & life \\
\hline 一生 & isshō & whole life & 17 & time \\
\hline 報告 & hōkoku & report & 16 & speech \\
\hline 話 & hanashi & story, talk & 14 & speech \\
\hline 説明 & setsumei & explanation & 14 & speech \\
\hline 戦争 & sensō & war & 12 & relationship \\
\hline 生涯 & shōgai & life & 11 & time \\
\hline 教科書 & kyōkasho & textbook & 8 & speech \\
\hline 食事 & shokuji & meal & 8 & life \\
\hline 回 & $k a i$ & -times & 7 & quantity \\
\hline 人生 & jinsei & life & 7 & life \\
\hline 時代 & jidai & period, era & 6 & time \\
\hline 全て & subete & everything, all & 6 & quantity \\
\hline 発言 & hatsugen & statement & 6 & speech \\
\hline 点前 & temae & $\begin{array}{l}\text { tea-ceremony } \\
\text { procedure }\end{array}$ & 6 & life \\
\hline 夢 & yume & dream & 5 & mental process \\
\hline 陳述 & chinjutsu & declaration & 5 & speech \\
\hline 質疑 & shitsugi & $\begin{array}{l}\text { question, } \\
\text { interpellation }\end{array}$ & 5 & speech \\
\hline 処理 & shori & processing, treatment & 5 & work \\
\hline
\end{tabular}

Table 7: List of collocations (owaru - CSJ/NUCC)

\begin{tabular}{lllll}
\hline & \multicolumn{3}{c}{ owaru - CSJ/NUCC } \\
Verb object & Transcription & Translation & Frequency & Semantic field \\
\hline 発表 & happyō & speech & 171 & speech \\
話 & hanashi & story, talk & 72 & speech \\
報告 & hōkoku & report & 18 & speech \\
説明 & setsumei & explanation & 4 & speech \\
仕事 & shigoto & work & 4 & life \\
幹部 & kanbu & executive & 3 & work \\
講演 & kōen & lecture & 3 & speech \\
スピーチ & supīchi & speech & 3 & speech
\end{tabular}




\begin{tabular}{|c|c|c|c|c|}
\hline \multicolumn{5}{|c|}{ owaru - CSJ/NUCC } \\
\hline Verb object & Transcription & Translation & Frequency & Semantic field \\
\hline 〜について (話) & $\begin{array}{l}\text { ni tsuite } \\
\text { (hanashi) }\end{array}$ & about (talk) & 2 & speech \\
\hline 授業 & jugyō & lesson & 2 & work \\
\hline 高校生以降 & kōkōsei ikō & $\begin{array}{l}\text { during/after high } \\
\text { school }\end{array}$ & 1 & time \\
\hline 野球部 & yakyūbu & baseball club & 1 & organization \\
\hline 発話 & hatsuwa & utterance, speech & 1 & speech \\
\hline 検索 & kensaku & searching & 1 & mental process \\
\hline 前夜祭 & zen'yasai & $\begin{array}{l}\text { night before a } \\
\text { festival }\end{array}$ & 1 & life \\
\hline 生活 & seikatsu & life & 1 & life \\
\hline 分析 & bunseki & analysis & 1 & mental process \\
\hline 文 & bun & sentence & 1 & speech \\
\hline 選手 & senshu & player & 1 & work \\
\hline 感想 & kansō & impression & 1 & mental process \\
\hline 町浦和 (話) & $\begin{array}{l}\text { machi urawa } \\
\text { (hanashi) }\end{array}$ & Urawa city (story) & 1 & speech \\
\hline 入力 & nyūryoku & input & 1 & work \\
\hline 小学校時代 & shōgakkō jidai & $\begin{array}{l}\text { time period of } \\
\text { primary school }\end{array}$ & 1 & time \\
\hline 戦争 & sensō & war & 1 & relationship \\
\hline コンパニオン & konpanion & companion & 1 & work \\
\hline これ (紛争) & kore (funsō) & this (dispute) & 1 & relationship \\
\hline ゲーム & gēmu & game & 1 & life \\
\hline 調べ & shirabe & investigation & 1 & mental process \\
\hline ヤマト & yamato & Yamato & 1 & person \\
\hline やつ & yatsu & he & 1 & person \\
\hline トーク & tōku & talk & 1 & speech \\
\hline ドクター & dokutā & doctor (PhD) & 1 & work \\
\hline ターゲット(目標) & $\begin{array}{l}\text { tāgetto } \\
\text { (mokuhyō) }\end{array}$ & target (objective) & 1 & mental process \\
\hline 食事 & shokuji & meal & 1 & life \\
\hline の (レポート) & no (repōto) & $\begin{array}{l}\text { nominalization } \\
\text { (report) }\end{array}$ & 1 & speech \\
\hline 子育て & kosodate & parenting & 1 & work \\
\hline それ (体験) & sore (taiken) & that (experience) & 1 & mental process \\
\hline それ (実習) & sore (jisshū) & that (practice) & 1 & mental process \\
\hline それ (説明) & sore (setsumei) & that (explanation) & 1 & speech \\
\hline
\end{tabular}


Once the results are summed up, it becomes apparent that over $75 \%$ of analyzed sentences include collocations classified into the semantic field of 'speech', such as 'question' (shitsumon 質問) or 'story' (hanashi 話). The most prominent group is followed by the semantic field of 'work', including collocations such as 'execution' (shikkō 執行). $6 \%$ of all collocations are sorted into the semantic field of 'life' ('life/lifetime' shōgai 生涯, 'life/living' seikatsu 生活). The remaining 5\% are evenly distributed between smaller groups (Table 8 and Figure 3).

Table 8: Semantic fields of collocations (owaru)

\begin{tabular}{llllllllll}
\hline & \multicolumn{1}{c}{ Time } & Person & Work & Speech Quantity & $\begin{array}{c}\text { Mental } \\
\text { process }\end{array}$ & \multicolumn{2}{c}{ Relationship } & Organization Life \\
\hline BCCWJ & 34 & 0 & 83 & 444 & 13 & 5 & 12 & 0 & 49 \\
& $5.3 \%$ & $0.0 \%$ & $13.0 \%$ & $69.4 \%$ & $2.0 \%$ & $0.8 \%$ & $1.9 \%$ & $0.0 \%$ & $7.7 \%$ \\
CSJ/NUCC & 8 & 2 & 10 & 279 & 0 & 7 & 2 & 1 & 8 \\
& $2.5 \%$ & $0.6 \%$ & $3.2 \%$ & $88.0 \%$ & $0.0 \%$ & $2.2 \%$ & $0.6 \%$ & $0.3 \%$ & $2.5 \%$ \\
Total & 42 & 2 & 93 & 723 & 13 & 12 & 14 & 1 & 57 \\
& $4.4 \%$ & $0.2 \%$ & $9.7 \%$ & $75.5 \%$ & $1.4 \%$ & $1.3 \%$ & $1.5 \%$ & $0.1 \%$ & $6.0 \%$ \\
\hline
\end{tabular}

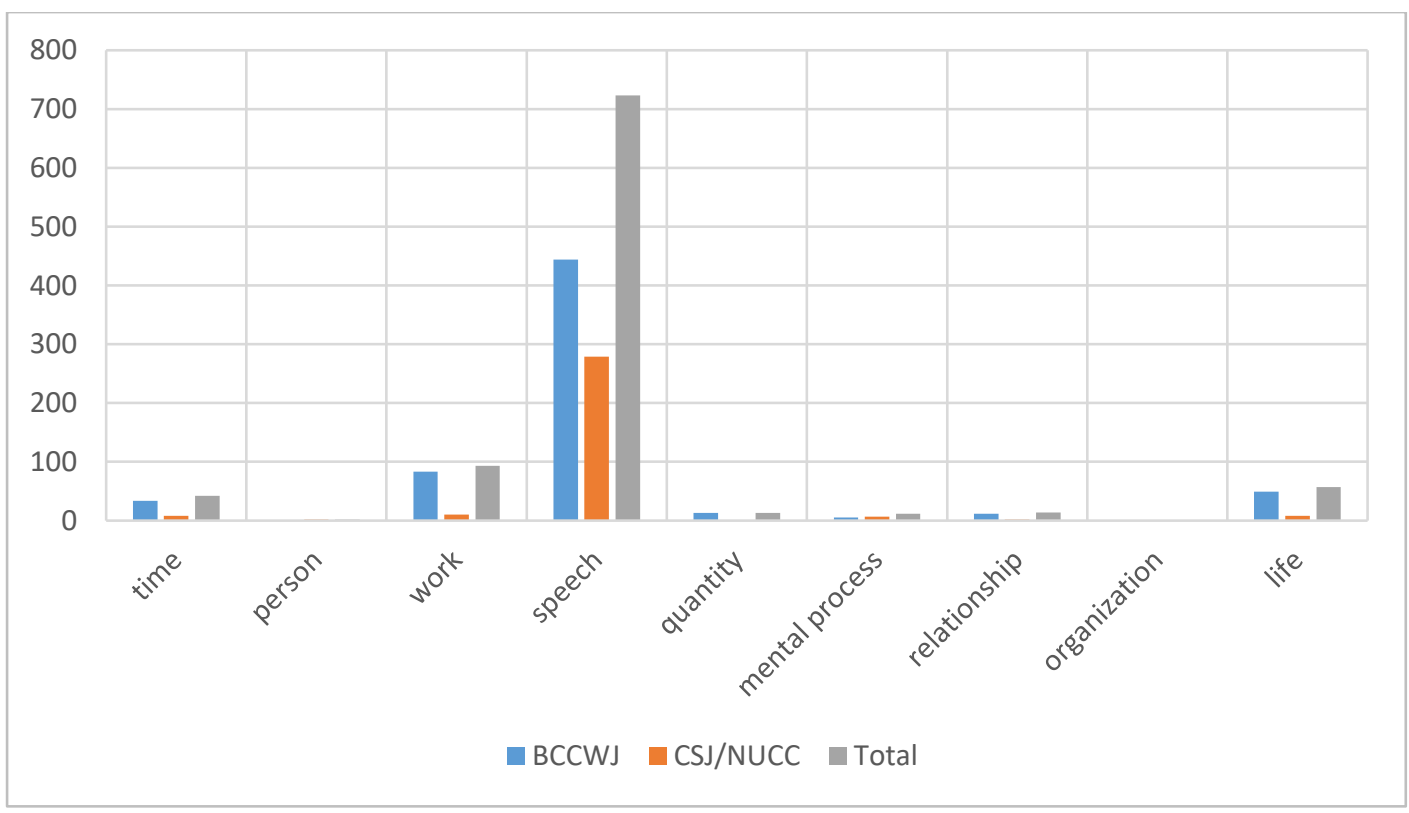

Figure 3: Semantic fields of collocations (owaru)

\subsection{Oeru}

Collocations are divided into seven semantic categories: 'time', 'work', 'speech', 'mental process', 'relationship', 'organization' and 'life'. All categories overlap with those observed in owaru. (see Tables 9 and 10). 
Table 9: List of collocations (oeru - BCCWJ)

\begin{tabular}{|c|c|c|c|c|}
\hline \multicolumn{5}{|c|}{ oeru - BCCWJ } \\
\hline Verb object & Transcription & Translation & Frequency & Semantic field \\
\hline 仕事 & shigoto & work & 189 & life \\
\hline 生涯 & shōgai & life & 63 & time \\
\hline 食事 & shokuji & meal & 62 & life \\
\hline 一生 & isshō & whole life & 57 & time \\
\hline 作業 & sagyō & work, duty & 51 & life \\
\hline 式 & shiki & ceremony & 42 & life \\
\hline 役割 & yakuwari & part, role & 40 & work \\
\hline 取引 & torihiki & trade, business & 34 & work \\
\hline 旅 & tabi & travel & 30 & life \\
\hline 役目 & yakume & duty, role & 29 & work \\
\hline 朝食 & chōshoku & breakfast & 27 & life \\
\hline 撮影 & satsuei & photography & 27 & work \\
\hline 話 & hanashi & story, talk & 26 & speech \\
\hline 準備 & junbi & preparation & 24 & mental process \\
\hline 生活 & seikatsu & life & 23 & life \\
\hline 授業 & jugyō & lesson & 23 & work \\
\hline 取材 & shuzai & collecting data & 22 & mental process \\
\hline 教育 & kyōiku & education & 21 & work \\
\hline 活動 & katsudō & activity & 20 & work \\
\hline 日 & hi & day & 20 & time \\
\hline 電話 & denwa & phone call & 20 & speech \\
\hline 生 & sei & life & 20 & life \\
\hline 夕食 & yūshoku & dinner & 19 & life \\
\hline 訓練 & kunren & training & 19 & work \\
\hline 出産 & shussan & birth, delivery & 19 & life \\
\hline 調査 & chōsa & survey & 18 & mental process \\
\hline 型 & kata & kata (sports) & 18 & life \\
\hline 手術 & shujutsu & surgery & 18 & work \\
\hline 練習 & renshū & exercise & 17 & mental process \\
\hline 戦 & $i k u s a$ & battle & 17 & relationship \\
\hline 会 & kai & meeting & 16 & organization \\
\hline 人生 & jinsei & life & 15 & life \\
\hline
\end{tabular}


Table 10: List of collocations (oeru - CSJ/NUCC)

\begin{tabular}{|c|c|c|c|c|}
\hline \multicolumn{5}{|c|}{ oeru - CSJ/NUCC } \\
\hline Verb object & Transcription & Translation & Frequency & Semantic field \\
\hline 仕事 & shigoto & work & 7 & life \\
\hline プログラム & puroguramu & program & 4 & speech \\
\hline 取引 & torihiki & trade, business & 4 & work \\
\hline 報告 & hōkoku & report & 3 & speech \\
\hline 学習 & gakushū & learning & 2 & mental process \\
\hline 出産 & shussan & birth, delivery & 2 & life \\
\hline 一生 & isshō & whole life & 3 & time \\
\hline 学校 (教育) & gakkō (kyōiku) & school (education) & 2 & work \\
\hline 旅 & tabi & travel & 2 & life \\
\hline 結婚式 & kekkonshiki & wedding & 2 & life \\
\hline 年間 & nenkan & in a year (period) & 1 & time \\
\hline 推論 & suiron & deduction & 1 & mental process \\
\hline 話 & hanashi & story, talk & 1 & speech \\
\hline 練習 & renshū & exercise & 1 & mental process \\
\hline 実習 & jisshū & practice & 1 & mental process \\
\hline 本番 & honban & performance & 1 & work \\
\hline 野球 & yakyū & baseball & 1 & life \\
\hline 生涯 & shōgai & life & 1 & time \\
\hline 生活 & seikatsu & life & 1 & life \\
\hline 授業 & jugyō & lesson & 1 & work \\
\hline 作業 & sagyō & work, duty & 1 & life \\
\hline 調査 & chōsa & survey & 1 & mental process \\
\hline 論文 & ronbun & thesis, article & 1 & speech \\
\hline 文 & bun & sentence & 1 & speech \\
\hline 挨拶 & aisatsu & greeting, address & 1 & speech \\
\hline 大役 & taiyaku & important role & 1 & work \\
\hline 合宿 & gasshuku & training camp & 1 & life \\
\hline 試合 & shiai & match, game & 1 & life \\
\hline 総会 & sōkai & general meeting & 1 & relationship \\
\hline 任 & $\operatorname{nin}$ & duty & 1 & work \\
\hline インターン & intān & intern & 1 & work \\
\hline 焼き入れ & yakiire & quenching & 1 & work \\
\hline 仕込み & shikomi & preparation & 1 & work \\
\hline コンパ & konpa & party, event & 1 & relationship \\
\hline $\begin{array}{l}\text { 〜っていうの (授 } \\
\text { 業) }\end{array}$ & tte iu no (jugyō) & $\begin{array}{l}\text { nominalization } \\
\text { (lesson) }\end{array}$ & 1 & work \\
\hline レジデント & rejidento & medical resident & 1 & work \\
\hline
\end{tabular}




\begin{tabular}{lllll}
\hline & \multicolumn{5}{c}{ oeru-CSJ/NUCC } & & \\
Verb object & Transcription & Translation & Frequency & Semantic field \\
\hline バイト & baito & part-time job & 1 & life \\
全て (葬列) & subete (sōretsu) & $\begin{array}{l}\text { everything, all } \\
\text { (funeral) }\end{array}$ & 1 & life \\
フェーズ & fēzu & phase & 1 & time \\
スパーリング & supāringu & sparring & 1 & life \\
フルメーク & furumēku & make-up & 1 & life \\
それ (仕事) & sore (shigoto) & that (work) & 1 & life \\
それ (教育) & sore (kyōiku) & that (education) & 1 & work \\
「みんなの日本 & Minna no nihongo & Minna no nihongo & 1 & speech \\
語」 1 (教科書) & 1 (kyōkasho) & 1 (textbook) & 1 & work \\
ドクター & dokutā & doctor (PhD) & 1 & \\
\hline
\end{tabular}

When compared to owaru, a noticeable difference in semantic distribution can be observed. Almost half (48.4\%) of all collocations are classified into the semantic field of 'life'. This category is followed by the semantic group of 'work', which amounts to a little less than a quarter of all collocations (22.3\%). The only other notable category is collocations related to 'time' with $13.1 \%$. The remaining groups are relatively small. It is worth pointing out that the largest semantic category of owaru, 'speech', only amounts to $5.2 \%$ within oeru (Table 11 and Figure 4).

Table 11: Semantic fields of collocations (oeru)

\begin{tabular}{llllllll}
\hline & Time & Work & Speech & $\begin{array}{l}\text { Mental } \\
\text { process }\end{array}$ & Relationship & Organization & Life \\
\hline BCCWJ & 140 & 231 & 46 & 81 & 17 & 16 & 515 \\
& $13.4 \%$ & $22.1 \%$ & $4.4 \%$ & $7.7 \%$ & $1.6 \%$ & $1.5 \%$ & $49.2 \%$ \\
CSJ/NUCC & 6 & 17 & 12 & 6 & 2 & 0 & 23 \\
& $9.1 \%$ & $25.8 \%$ & $18.2 \%$ & $9.1 \%$ & $3.0 \%$ & $0.0 \%$ & $34.8 \%$ \\
Total & 146 & 248 & 58 & 87 & 19 & 16 & 538 \\
& $13.1 \%$ & $22.3 \%$ & $5.2 \%$ & $7.8 \%$ & $1.7 \%$ & $1.4 \%$ & $48.4 \%$ \\
\hline
\end{tabular}




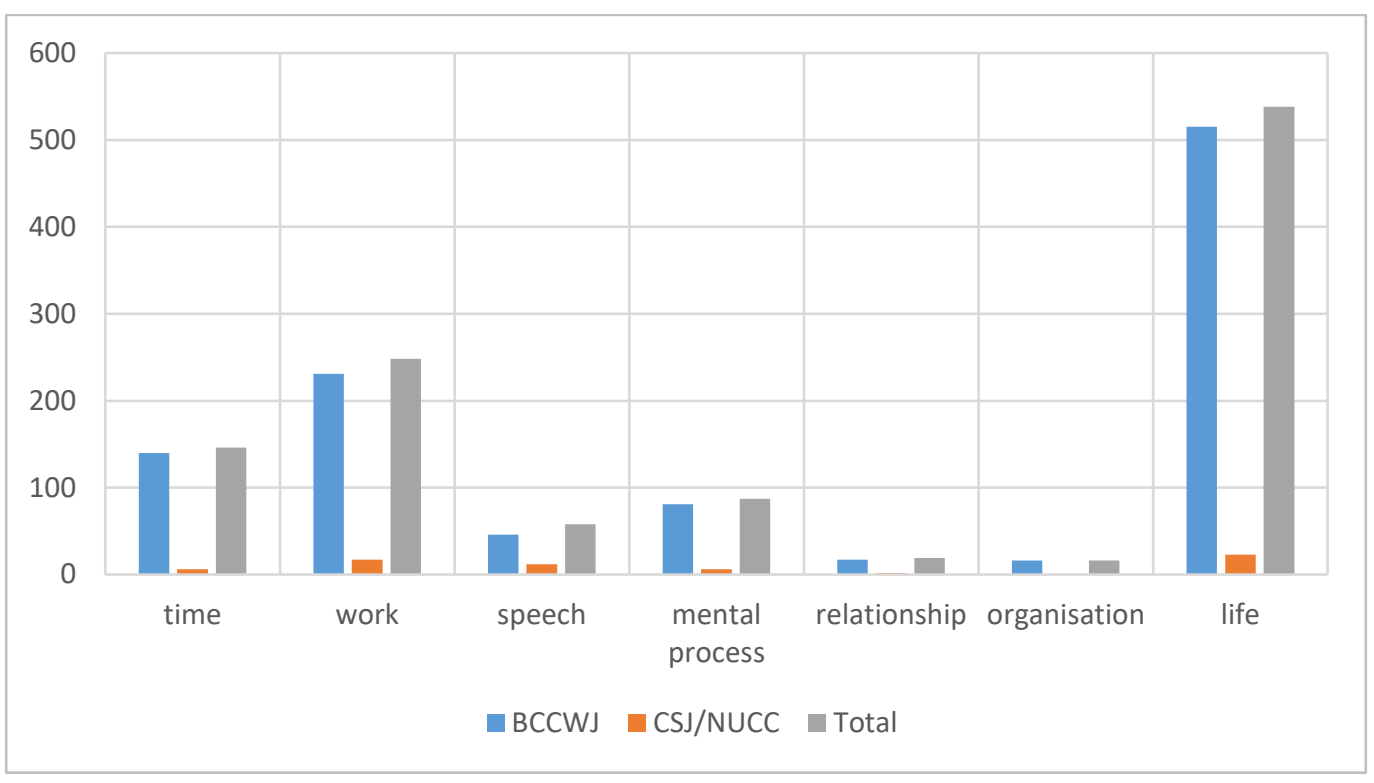

Figure 4: Semantic fields of collocations (oeru)

\section{Categorization of verb forms and collocations}

This section discusses the categorization of verb forms.

Analyzed verbs were first grouped into six categories according to the voice (voisu, tai ヴオイス, 態) or modality (modariti, hōモダリティ, 法) they display. Due to an already high number of results, only verb forms exhibiting modality through inflection were counted.

Furthermore, almost all verbs in modality categories are found in the active voice. There are six exceptions where a combination of two morphemes can be observed (causative + volition, causative + desire). Such exceptions are only found in examples of the verb owaru and were assigned to both categories (see 6.1). Once categorized, all verb forms were further classified into eight subcategories (see 6.2).

All samples were exported in an .xslx file and analyzed manually. Both categories and subcategories are based on verb forms appearing throughout sample sentences. Verb forms not observed within examples of either owaru or oeru are therefore not included.

When a verb form corresponded to one of the categories or subcategories, a point was assigned in the designated table. Two examples of point-counting are given at the end of this section (refer to Tables 12 and 13 below). This was done in order to determine the distribution of verb forms within example sentences and, most importantly, within semantic groups of collocations (Sections 7 and 8). 
Both categories and subcategories as well as example sentences representative of each are provided on the following pages (Sections 6.1 and 6.2).

\subsection{Categories of verb forms}

1. Active form

Active voice of the verb, including the final form shūshikei 終止形 and attributive form rentaikei 連体形.

1) 彼の言うには、神、すなわち、われわれとわれわれの周りの人間の創造 者は、その仕事を終える前に死んだというのです。

Kare no iu ni wa, kami, sunawachi, wareware to wareware no mawari no ningen no sōzōsha wa, sono shigoto wo oeru mae ni shinda to iu no desu.

work [acc] to finish [tr.act.nonpst.adn]

According to his words, God, the creator of us and others, died before he finished his work.

2. Causative form

Causative voice (-(s)ase-) of the verb.

2) 時間内に仕事を終わらせることも大切な責任です。

Jikannai ni shigoto wo owaraseru koto mo taisetsu na sekinin desu.

work [acc] to finish [tr.caus.nonpst.adn]

Finishing work within the time frame is just as big of a responsibility.

3. Passive/potential/honorific form

Indicates the passive form, potential form, or honorific form of the verb (-rare-).

Out of seven cases, five verbs (including Example 3 below), are used as honorific speech. Four co-occur with nouns meaning 'life', such as 'shōgai 生涯' or 'isshō一生', while one is used in dialogue as a direct question 'have you completed your PhD?' (dokutā wo owarareta no desu ka ドクターを終わられたのですか).

One example is ambiguous and can be interpreted as either the potential or as the honorific form - 'you, who were able to safely complete your duty' or 'you, who safely completed your duty' (buji oyakume wo oerareta anata 無事お役目を終えられた貴 万).

The last example is a direct question referring to a third party. Oeru is used in its potential form - 'do you think the villagers will be able to finish the long journey?' (murabitotachi wa [...] nagai tabi wo oerareru to omoimasuka? 村人たちは [...] 長い 旅を終えられると思いますか?). 
There are no examples of either verb in its passive form.

3)しかし、不幸なことに二年たらずで大腸がんにかかり、五十五歳の短い 生涯を終えられました。

Shikashi, fukō na koto ni ninen tarazu de daichōgan ni kakari, gojūgosai no mijikai shōgai wo oeraremashita.

life [acc] to end [tr.pol.pst]

However, unfortunately, in less than two years, he fell ill with colorectal cancer and ended his short life at the age of 55.

4. Volition

Verb form expressing volition $(-(y) \overline{0})$.

4) ちょうどその仕事を終えようとしたとき、エレベーターの動く音がし た。

Chōdo sono shigoto wo oeyō to shita toki, erebēta no ugoku oto ga shita. work [acc] to finish [tr.act.vol]

Just as I was about to finish work, I heard the sound of the elevator moving.

5. Desire

Verb form expressing desire, wish (-tai).

5) この二点御答弁いただいて、質問を終わりたいと思います。 Kono niten gotōben itadaite, shitsumon wo owaritai to omoimasu. question [acc] to end [tr.act.des.nonpst]

Once you provide an explanation of these two points, I would like to end my question.

6. Gerundive/-te form

The gerundive or -te form of the active voice. It is generally a subcategory (see 6.2), but separated in the case of active voice due to a very high frequency of appearance.

6) 仕事を終えて味わう酒は本当に美味。

Shigoto wo oete ajiwau sake wa hontō ni bimi.

work [acc] to finish [tr.act.ger]

Alcohol savored after work is truly delicious. 


\subsection{Subcategories of verb forms}

Subcategories highlight additional characteristics of the verbs. The eight groups are classified as follows.

1. Positive form

Positive form of the verb.

7) あの子は親の名前も顔も知らないわずか十余年の短い生涯を終えた。 Ano ko wa oya no namae mo kao mo shiranai wazuka jūyonen no mijikai shōgai wo oeta.

life [acc] to end [tr.act.pst.pos]

That child ended his short life of ten years or so without knowing the names and faces of his parents.

2. Negative form

Negative form of the verb.

8) 業者さんがとにかく仕事を終わらせないと帰れないのです。

Gyōsha san ga tonikaku shigoto wo owarasenai to kaerenai no desu.

work [acc] to finish [tr.caus.nonpst.neg]

In any case, workers cannot go home if they do not finish work.

3. Non-past form

The verb is found in non-past tense.

9) 以上で発表を終わります。

Ijō de happyō wo owarimasu.

presentation [acc] to end [tr.act.pol.nonpst]

With this I end my presentation.

4. Past form

The verb is found in past tense.

10) 小坂はあわてて話を終わらせた。

Kosaka wa awatete hanashi wo owaraseta.

story [acc] to finish [tr.caus.pst]

Kosaka hurriedly finished the story. 


\section{Past context}

The context of an analyzed sentence as a whole is placed in the past. The category was added in order to compare the use of tenses between owaru and oeru. For example, the gerundive form of oeru (oete) does not indicate past nor non-past on its own. However, it frequently appears within sentences where the main verb is used in past tense.

11) ほどなく、彼は話を終えて戻ってきた。

Hodonaku, kare wa hanashi wo oete modotte kita.

story [acc] to finish [tr.act.ger]

Soon after, he finished the story and came back.

\section{Adnominal use}

The verb is used adnominally in the structure V-ru $+\mathrm{N}$.

12) 効率よく仕事を終わらせるコツ。

Kōritsu yoku shigoto wo owaraseru kotsu.

work [acc] to finish [tr.caus.nonpst.adn]

The secret to finishing work effectively.

\section{Gerundive/-te form'}

The gerundive form of all categories with the exception of active voice. In order to differentiate it from the main category, it is marked with the apostrophe sign '.

13) 以上、私の所見を交え、質問を終わらせていただきます。

ıjō, watashi no shoken wo majie, shitsumon wo owarasete itadakimasu.

question [acc] to finish [tr.caus.ger]

With this, I have expressed my opinion and will now finish my question.

\section{Conditional form}

-ba and -tara forms.

14）食事を終わったら、君の客室へ行って話し合おうか?

Shokuji wo owattara, kimi no kyakushitsu e itte hanashiaō ka?

meal [acc] to finish [tr.act.cond]

After we finish the meal, shall we head to your room and talk?

The following Tables 12 and 13 present examples of point assignment during the analysis. The first row lists the category, while the second one lists the subcategories. When the verb form coincides with one of the subcategories, one point ' 1 ' is added to 
the chart. If the verb form does not correspond to any category, no points ' 0 ' were assigned.

Example for the sentence 'allow me to finish my presentation' (happyō wo owarasete itadakimasu 発表を終わらせていただきます):

Table 12: Point assignment 1

\begin{tabular}{llllllll}
\hline & \multicolumn{7}{c}{ Causative } \\
Positive & Negative & Non-past & Past & Past context & Adnominal & Gerundive' & Conditional \\
\hline 1 & 0 & 0 & 0 & 0 & 0 & 1 & 0 \\
\hline
\end{tabular}

Example for the sentence 'after finishing work, I read a book' (shigoto wo oeta ato hon wo yomimashita 仕事を終えた後本を読みました):

Table 13: Point assignment 2

\begin{tabular}{llllllll}
\hline & & \multicolumn{7}{c}{ Active } \\
Positive & Negative & Non-past & Past & Past context & Adnominal & Gerundive' & Conditional \\
\hline 1 & 0 & 0 & 1 & 1 & 1 & 0 & 0 \\
\hline
\end{tabular}

Once each verb form was analyzed in line with this procedure, points were summed up and edited in the form of tables and graphs. These provide a picture of the morphological distribution in two corpora separately as well as a general picture (total) where all results are counted together. This made it possible to easily determine the frequency of morphological categories and subcategories, presented in the upcoming Section 7, and, additionally, determine their relation to the semantic fields (Section 8).

\section{Frequency of morphological verb categories and subcategories}

In this section results of the sentence, analysis are provided. For practical reasons the forms owarareru and oerareru are marked as 'honorific' in tables and figures, as they are the highest in frequency (refer to Section 6.1).

\subsection{Owaru}

\subsubsection{Categories}

Over half of all examples find owaru in its active form (55.2\%). Causative use is placed second, with $19.3 \%$ of appearance frequency. In this case, the high number is to be expected. As pointed out in Section 2.3, as well as during the analysis of instructional materials and the public's general perception of owaru, the verb is consistently being 
presented or perceived as solely intransitive. Two smaller groups consist of the gerundive owatte (10.7\%) and the form expressing desire owaritai (13.8\%). Meanwhile, the volitional form owaro $(0.9 \%)$ and the honorific form owarareru $(0.1 \%)$ are barely present (see Table 14 and Figure 5).

Table 14: Verb forms (owaru)

\begin{tabular}{lllllll}
\hline & $\begin{array}{l}\text { owaru } \\
\text { active }\end{array}$ & $\begin{array}{l}\text { owaraseru } \\
\text { causative }\end{array}$ & $\begin{array}{l}\text { owarareru } \\
\text { honorific }\end{array}$ & $\begin{array}{l}\text { owarō } \\
\text { volition }\end{array}$ & $\begin{array}{l}\text { owaritai } \\
\text { desire }\end{array}$ & $\begin{array}{l}\text { owatte } \\
\text { gerundive }\end{array}$ \\
\hline BCCWJ & 301 & 99 & 0 & 5 & 97 & 84 \\
& $51.4 \%$ & $16.9 \%$ & $0.0 \%$ & $0.9 \%$ & $16.6 \%$ & $14.3 \%$ \\
CSJ/NUCC & 195 & 74 & 1 & 3 & 27 & 12 \\
& $62.5 \%$ & $23.7 \%$ & $0.3 \%$ & $1.0 \%$ & $8.7 \%$ & $3.8 \%$ \\
Total & 496 & 173 & 1 & 8 & 124 & 96 \\
& $55.2 \%$ & $19.3 \%$ & $0.1 \%$ & $0.9 \%$ & $13.8 \%$ & $10.7 \%$ \\
\hline
\end{tabular}

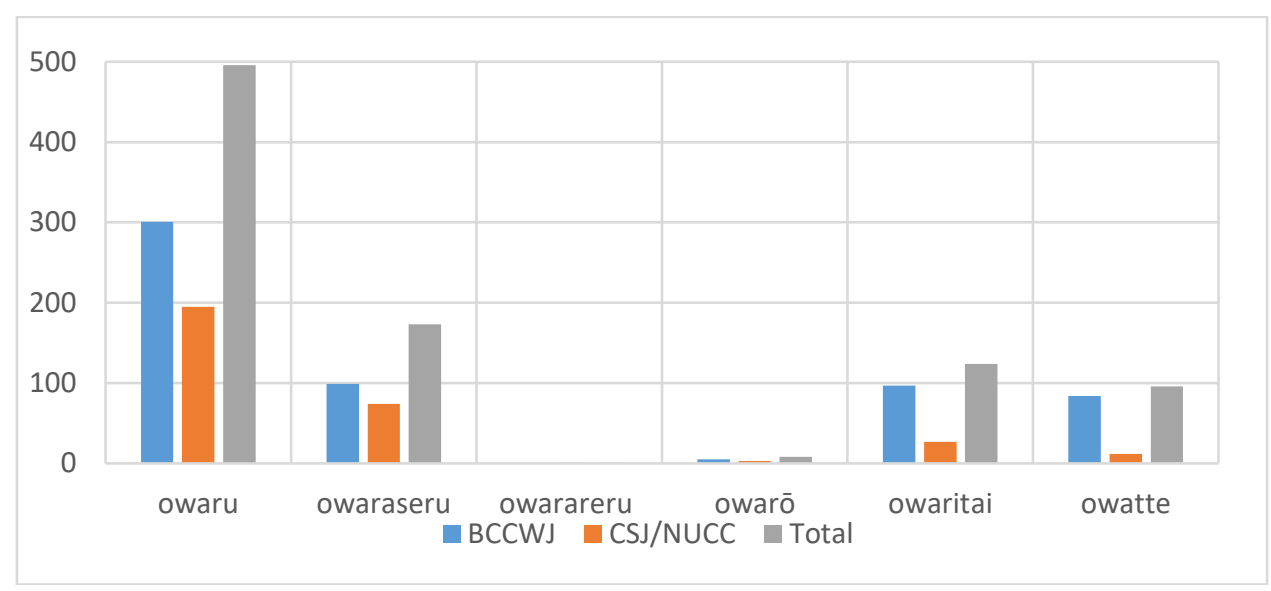

Figure 5: Verb forms (owaru)

When comparing the corpora of written (BCCWJ) and spoken (CSJ/NUCC) Japanese, the most remarkable difference can be found in the causative use of owaru. The active form is the most notable in both corpora and encompasses over $60 \%$ of the forms in CSJ/NUCC.

However, the causative use is more prevalent in the corpus of spoken Japanese $(23.7 \%)$, whereas the frequency in BCCWJ reaches only $16.9 \%$. The reason for this difference could be assigned to one specific collocation, 'presentation, speech' happyō 発表. It is ranked first in frequency and frequently co-occurs with the phrase 'allow to finish' owarasete itadaku 終わらせていただく. This structure consists of the causative morpheme -(s)ase- and the verb 'to receive' in its humble form itadaku. It can be used when the speaker is granted permission from the listener for a specific action, or as a phrase when there is no actual need for permission and the speaker 
simply wants to express politeness or humbleness when talking about a planned action (Shigemori Bučar, 2008, p. 76-77).

BCCWJ on the contrary exhibits a higher percentage of the form owaritai, which most frequently co-occurs with the collocation 'question' shitsumon 質問 in the phrase ‘I think I want to finish’ owaritai to omoimasu 終わりたいと思います.

\subsubsection{Subcategories}

The verb owaru is found almost entirely in its positive form (99.2\%) and non-past tense $(86.5 \%)$. Even considering the context in its entirety, the past tense of the main verb can only be observed in 50 cases (Table 15 and Figure 6).

Gerundive forms are visible especially in the category of causative use (owarasete), which is due to the frequently used phrase owarasete itadaku. In this research, this structure most often co-occurs with collocations in the semantic field of 'speech', such as 'question' shitsumon 質問, 'presentation' happyō 発表 or 'story' hanashi 話. As this semantic group is the most prominent for owaru, the high percentage of causative use and gerundive forms are not unexpected. The latter is particularly present in CSJ/NUCC. There are no other significant differences between the two corpora.

Table 15: Subcategories of verb forms (owaru)

\begin{tabular}{lllllllll}
\hline & Positive & Negative & Non-past & Past & Past context & Adnominal & Gerundive' & Conditional \\
\hline BCCWJ & 581 & 5 & 482 & 20 & 37 & 35 & 73 & 2 \\
& $99.1 \%$ & $0.9 \%$ & $82.3 \%$ & $3.4 \%$ & $6.3 \%$ & $6.0 \%$ & $12.5 \%$ & $0.3 \%$ \\
CSJ/NUCC & 310 & 2 & 295 & 5 & 13 & 12 & 65 & 2 \\
& $99.4 \%$ & $0.6 \%$ & $94.6 \%$ & $1.6 \%$ & $4.2 \%$ & $3.8 \%$ & $20.8 \%$ & $0.6 \%$ \\
\multirow{4}{*}{ Total } & 891 & 7 & 777 & 25 & 50 & 47 & 138 & 4 \\
& $99.2 \%$ & $0.8 \%$ & $86.5 \%$ & $2.8 \%$ & $5.6 \%$ & $5.2 \%$ & $15.4 \%$ & $0.4 \%$ \\
\hline
\end{tabular}




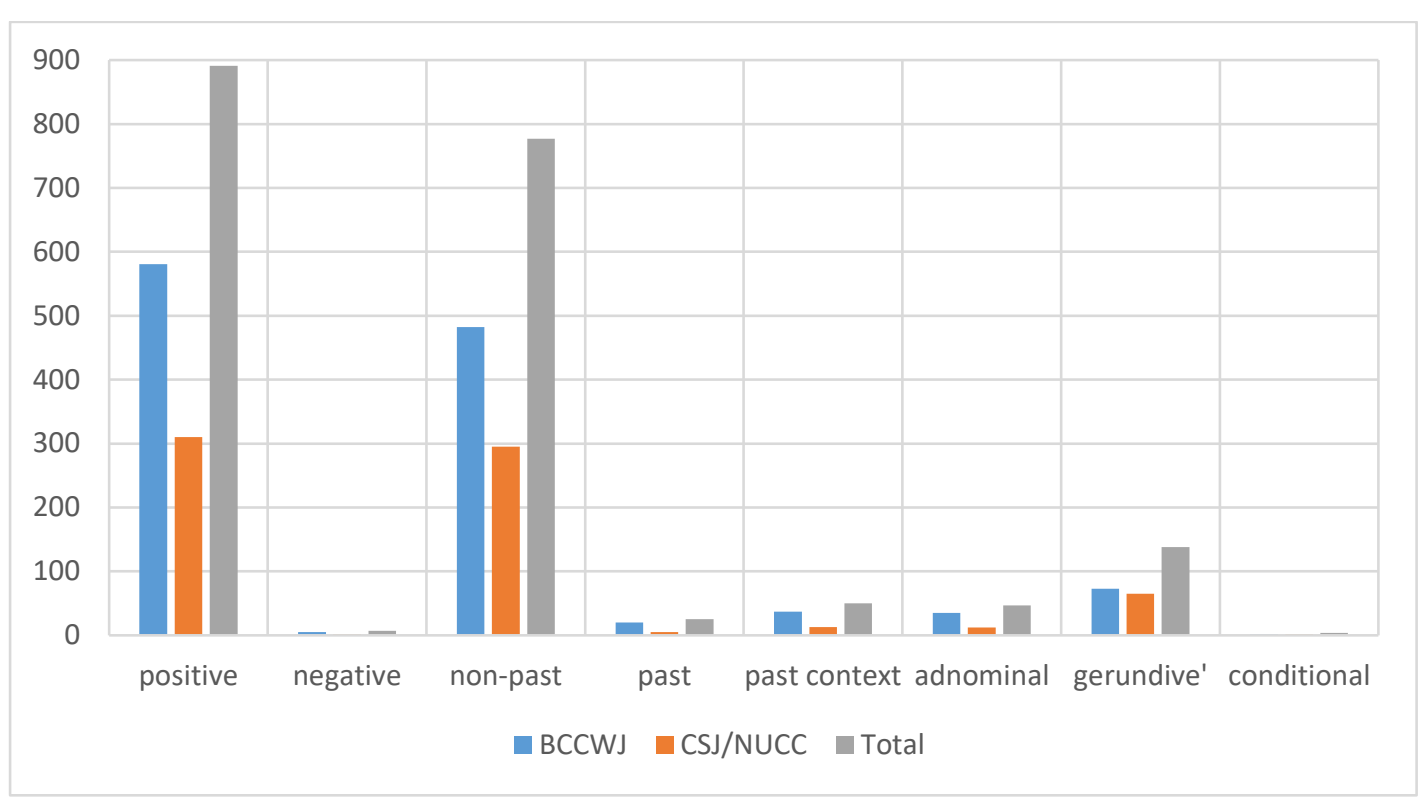

Figure 6: Subcategories of verb forms (owaru)

\subsection{Oeru}

\subsubsection{Categories}

In contrast with the verb owaru, the distribution of categories is significantly different for oeru. Only two major groups can be identified; the active form taking up almost $60 \%$ of all examples and the gerundive form amounting to almost $40 \%$. If counted together, the two groups make up for $95.8 \%$ of all analyzed verb forms.

No other form, including the causative use, stands out (Table 16 and Figure 7).

Table 16: Categories of verb forms (oeru)

\begin{tabular}{lllllll}
\hline & $\begin{array}{l}\text { oeru } \\
\text { active }\end{array}$ & $\begin{array}{l}\text { oesaseru } \\
\text { causative }\end{array}$ & $\begin{array}{l}\text { oerareru } \\
\text { honorific }\end{array}$ & $\begin{array}{l}\text { oeyō } \\
\text { volition }\end{array}$ & $\begin{array}{l}\text { oetai } \\
\text { desire }\end{array}$ & $\begin{array}{l}\text { oete } \\
\text { gerundive }\end{array}$ \\
\hline BCCWJ & 369 & 0 & 6 & 7 & 10 & 231 \\
& $59.2 \%$ & $0.0 \%$ & $1.0 \%$ & $1.1 \%$ & $1.6 \%$ & $37.1 \%$ \\
CSJ/NUCC & 34 & 3 & 0 & 1 & 2 & 26 \\
& $51.5 \%$ & $4,5 \%$ & $0.0 \%$ & $1.5 \%$ & $3.0 \%$ & $39.4 \%$ \\
Total & 403 & 3 & 6 & 8 & 12 & 257 \\
& $58.5 \%$ & $0.4 \%$ & $0.9 \%$ & $1.2 \%$ & $1.7 \%$ & $37.3 \%$ \\
\hline
\end{tabular}




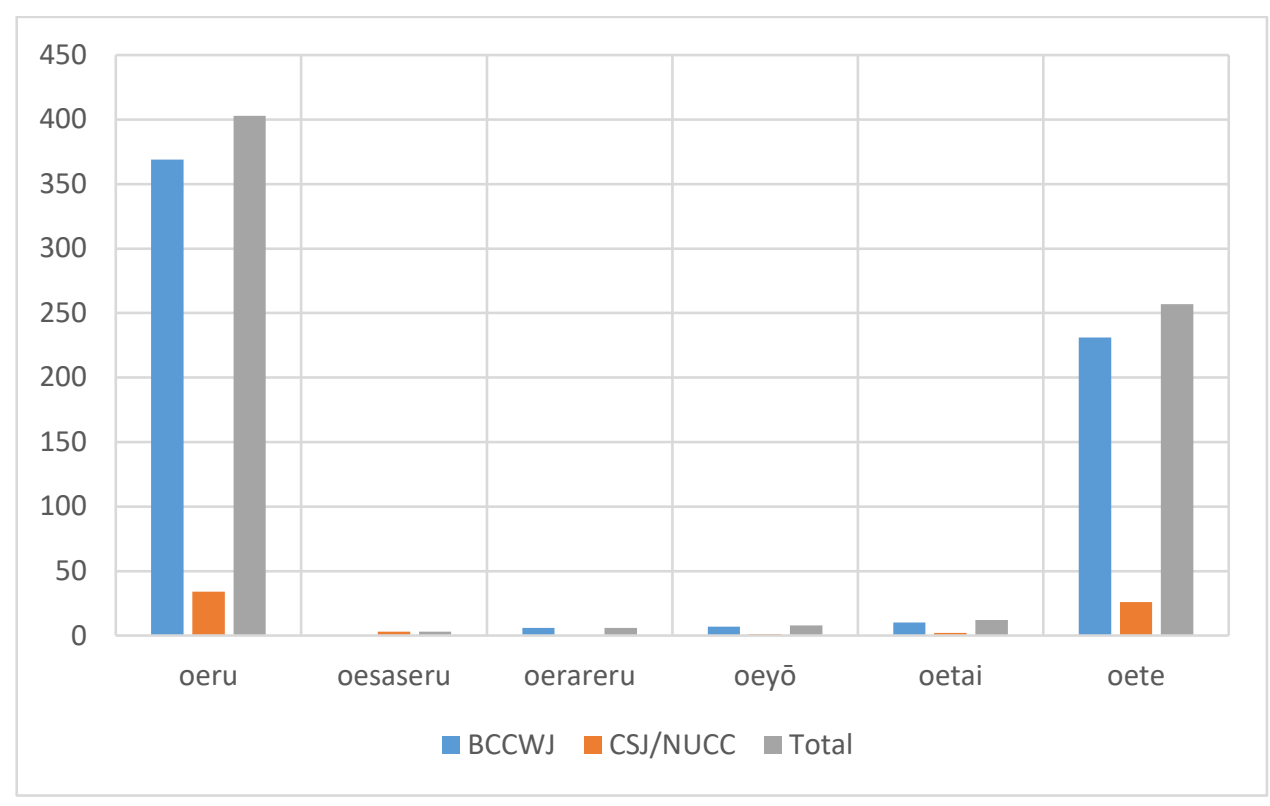

Figure 7: Categories of verb forms (oeru)

As explained in Section 7.1, causative use is primarily found co-occurring with collocations in the semantic field of 'speech'. However, such collocations are not as frequent when discussing oeru. The lack of this category could be an explanation for the low percentage of causative forms when compared to owaru.

There are no significant differences between the corpora of written and spoken Japanese. However, two minor discrepancies can be mentioned; all causative forms are observed in CSJ/NUCC, while all honorific forms are located in BCCWJ.

\subsubsection{Subcategories}

It is worth noting one major discrepancy can be observed when comparing the results with those of the verb owaru.

While the absence of negative forms is characteristic of both verbs, the use of the tense is significantly different. Oeru is found in past tense in the majority of cases (past tense 271 cases, non-past tense 150 cases), and past context prevails as well (395 cases out of 689). Adnominal use is also often found in past forms.

The gerundive' group has an extremely low frequency $(0.4 \%)$, which can however be explained with the gerundive of the active form being a separate category. (Table 17 and Figure 8).

The distribution of forms (active and gerundive forms covering over $95 \%$ of all verb forms) and the major use of both past tense and past context suggest that oeru is a verb that tends to express 'completion'. Past tense and past context on their own define an action that has already been finished. Furthermore, the gerundive also 
implies a sequence of two or more actions, in which the first one has to be completed before the next one begins.

Other than a higher percentage of the 'past context' category observed in BCCWJ, no major differences between the corpora of written and spoken Japanese are present.

Table 17: Subcategories of verb forms (oeru)

\begin{tabular}{lllllllll}
\hline & Positive & Negative & Non-past & Past & Past context & Adnominal & Gerundive' & Conditional \\
\hline BCCWJ & 623 & 0 & 139 & 246 & 368 & 178 & 0 & 8 \\
& $100.0 \%$ & $0.0 \%$ & $22.3 \%$ & $39.5 \%$ & $59.1 \%$ & $28.6 \%$ & $0.0 \%$ & $1.3 \%$ \\
CSJ/NUCC & 66 & 0 & 11 & 25 & 27 & 21 & 3 & 3 \\
& $100.0 \%$ & $0.0 \%$ & $16.7 \%$ & $37.9 \%$ & $40.9 \%$ & $31.8 \%$ & $4.5 \%$ & $4.5 \%$ \\
\multirow{5}{*}{ Total } & 689 & 0 & 150 & 271 & 395 & 199 & 3 & 11 \\
& $100.0 \%$ & $0.0 \%$ & $21.8 \%$ & $39.3 \%$ & $57.3 \%$ & $28.9 \%$ & $0.4 \%$ & $1.6 \%$ \\
\hline
\end{tabular}

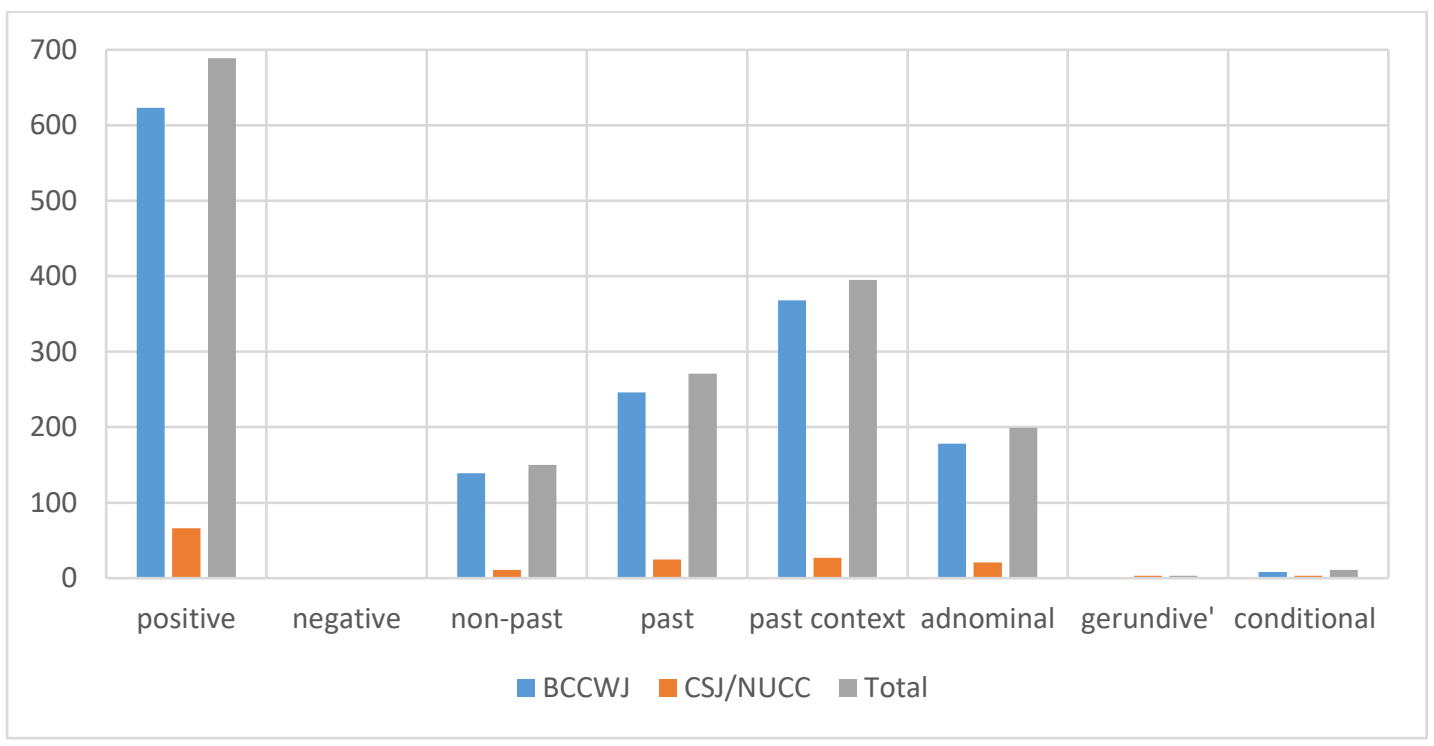

Figure 8: Subcategories of verb forms (oeru) 


\section{Collocations in relation to verb forms}

This section provides the analysis of relations between semantic fields of collocations and morphological categories of verb forms. Only collocations of higher frequency cooccurring with analyzed verb forms are counted (refer to Section 4).

The tables in this section list all semantic fields of collocations and their frequency of appearance, as well as the morphological categories of each verb.

Full lists of collocations belonging to separate semantic fields can be found in Sections 5.1 and 5.2. Morphological categories are described in detail in Section 6.

Each table corresponds to the graph located beneath it. Sections on the graphs represent the distribution of verbal forms within a specific semantic group of collocations.

\subsection{Owaru}

The most prominent semantic group of collocations for the verb owaru is that of 'speech' (refer to Section 5). Numbers in Table 18 show that collocations in this field most frequently (62.9\%) co-occur with active forms of the verb. Additionally, in the same semantic field, there are two other emerging morphological categories; the causative form owaraseru (19.3\%) and the form expressing desire owaritai (17.2\%).

Collocations classified into the semantic field of 'work' show a high co-occurrence of $85.2 \%$ with the gerundive form owatte, as well as the active form (12.5\%). The remaining morphological categories fluctuate between $0-1.1 \%$.

Similarly, the semantic groups of 'life', 'time', and 'relationship', although lesser in frequency, also show that the most prominent morphological categories are those of active, causative, and gerundive forms.

Other semantic groups of collocations are not common and show no particular relations in regards to any morphological category of the verbs.

Table 18: Collocations in relation to verb forms (owaru)

\begin{tabular}{llllllll}
\hline Semantic field & Frequency & $\begin{array}{l}\text { owaru } \\
\text { active }\end{array}$ & $\begin{array}{l}\text { owaraseru } \\
\text { causative }\end{array}$ & $\begin{array}{l}\text { owarareru } \\
\text { honorific }\end{array}$ & $\begin{array}{l}\text { owarō } \\
\text { volition }\end{array}$ & $\begin{array}{l}\text { owaritai } \\
\text { desire }\end{array}$ & $\begin{array}{l}\text { owatte } \\
\text { gerundive }\end{array}$ \\
\hline Time & 30 & 21 & 1 & 0 & 1 & 2 & 6 \\
& & $70.0 \%$ & $3.3 \%$ & $0.0 \%$ & $3.3 \%$ & $6.7 \%$ & $20.0 \%$ \\
Person & 2 & 0 & 2 & 0 & 0 & 0 & 0 \\
& & $0.0 \%$ & $100.0 \%$ & $0.0 \%$ & $0.0 \%$ & $0.0 \%$ & $0.0 \%$ \\
Work & 88 & 11 & 1 & 1 & 0 & 0 & 75 \\
& & $12.5 \%$ & $1.1 \%$ & $1.1 \%$ & $0.0 \%$ & $0.0 \%$ & $85.2 \%$
\end{tabular}




\begin{tabular}{llllllll}
\hline Semantic field & Frequency & $\begin{array}{l}\text { owaru } \\
\text { active }\end{array}$ & $\begin{array}{l}\text { owaraseru } \\
\text { causative }\end{array}$ & $\begin{array}{l}\text { owarareru } \\
\text { honorific }\end{array}$ & $\begin{array}{l}\text { owaro } \\
\text { volition }\end{array}$ & $\begin{array}{l}\text { owaritai } \\
\text { desire }\end{array}$ & $\begin{array}{l}\text { owatte } \\
\text { gerundive }\end{array}$ \\
\hline Speech & 699 & 440 & 135 & 0 & 3 & 120 & 2 \\
& & $62.9 \%$ & $19.3 \%$ & $0.0 \%$ & $0.4 \%$ & $17.2 \%$ & $0.3 \%$ \\
Mental & 7 & 3 & 1 & 0 & 1 & 0 & 2 \\
process & & $42.9 \%$ & $14.3 \%$ & $0.0 \%$ & $14.3 \%$ & $0.0 \%$ & $28.6 \%$ \\
Relationship & \multirow{2}{*}{14} & 2 & 12 & 0 & 0 & 1 & 0 \\
& & $14.3 \%$ & $85.7 \%$ & $0.0 \%$ & $0.0 \%$ & $7.1 \%$ & $0.0 \%$ \\
Organization & \multirow{2}{*}{1} & 1 & 0 & 0 & 0 & 0 & 0 \\
& & $100.0 \%$ & $0.0 \%$ & $0.0 \%$ & $0.0 \%$ & $0.0 \%$ & $0.0 \%$ \\
Life & 51 & 18 & 21 & 0 & 3 & 1 & 11 \\
& & $35.3 \%$ & $41.2 \%$ & $0.0 \%$ & $5.9 \%$ & $2.0 \%$ & $21.6 \%$ \\
\hline
\end{tabular}

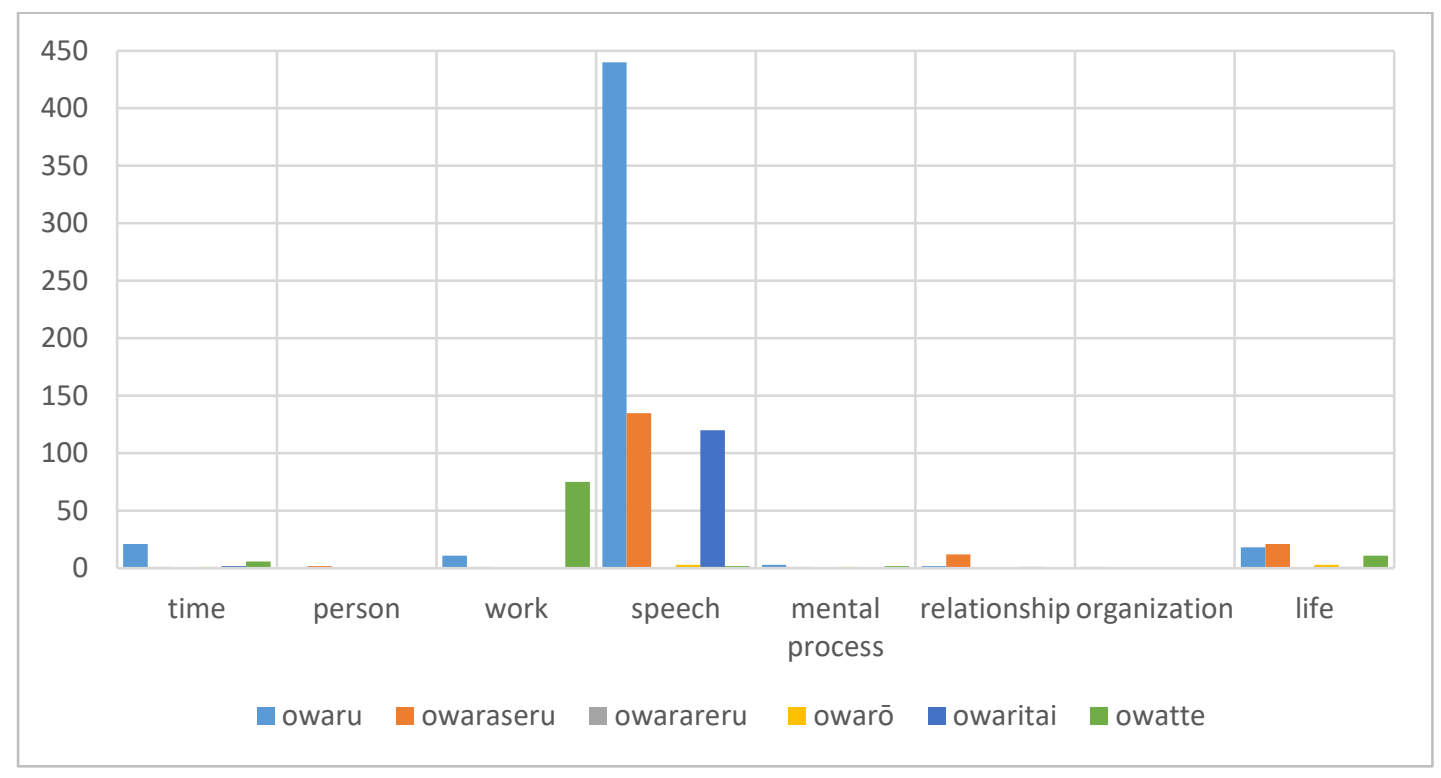

Figure 9: Collocations in relation to verb forms (owaru)

\subsection{Oeru}

The results of collocations in relation to verbal forms of oeru are consistent with the semantical and morphological analysis (Sections 5 and 7).

In all semantic fields, the most noticeable morphological are of the active voice oeru and the gerundive form oete (see Table 19 and Figure 10).

Only one exception can be observed. In line with the results of owaru, the verb oeru also displays a higher percentage of causative oesaseru, as well as the form expressing desire oetai, in the semantic field of 'speech'. Causative is only observable 
in this semantic field. Each morphological category constitutes $7.9 \%$ of analyzed verb forms, whereas in owaru causative is prevalent.

This pattern of distribution can be anticipated, as the analysis of the morphological categories (Section 7) reveals that oeru is largely observed in either its active or its gerundive form.

The remaining categories (causative, honorific, volition and desire) are, except for the abovementioned semantic group of 'speech', very low in percentage or not observed in several cases.

Table 19: Collocations in relation to verb forms (oeru)

\begin{tabular}{llllllll}
\hline Semantic field & Frequency & $\begin{array}{l}\text { oeru } \\
\text { active }\end{array}$ & $\begin{array}{l}\text { oesaseru } \\
\text { causative }\end{array}$ & $\begin{array}{l}\text { oerareru } \\
\text { honorific }\end{array}$ & $\begin{array}{l}\text { oeyō } \\
\text { volition }\end{array}$ & $\begin{array}{l}\text { oetai } \\
\text { desire }\end{array}$ & $\begin{array}{l}\text { oete } \\
\text { gerundive }\end{array}$ \\
\hline Time & 126 & 101 & 0 & 4 & 2 & 5 & 14 \\
& & $80.2 \%$ & $0.0 \%$ & $3.2 \%$ & $1.6 \%$ & $4.0 \%$ & $11.1 \%$ \\
Work & \multirow{2}{*}{120} & 88 & 0 & 1 & 3 & 2 & 26 \\
& & $73.3 \%$ & $0.0 \%$ & $0.8 \%$ & $2.5 \%$ & $1.7 \%$ & $21.7 \%$ \\
Speech & \multirow{2}{*}{38} & 18 & 3 & 0 & 0 & 3 & 14 \\
& & $47.4 \%$ & $7.9 \%$ & $0.0 \%$ & $0.0 \%$ & $7.9 \%$ & $36.8 \%$ \\
Mental process & 6 & 4 & 0 & 0 & 0 & 0 & 2 \\
& & $66.7 \%$ & $0.0 \%$ & $0.0 \%$ & $0.0 \%$ & $0.0 \%$ & $33.3 \%$ \\
Relationship & 2 & 2 & 0 & 0 & 0 & 0 & 0 \\
& & $100.0 \%$ & $0.0 \%$ & $0.0 \%$ & $0.0 \%$ & $0.0 \%$ & $0.0 \%$ \\
Life & \multirow{2}{*}{397} & 190 & 0 & 1 & 3 & 2 & 201 \\
& & $47.9 \%$ & $0.0 \%$ & $0.3 \%$ & $0.8 \%$ & $0.5 \%$ & $50.6 \%$ \\
\hline
\end{tabular}

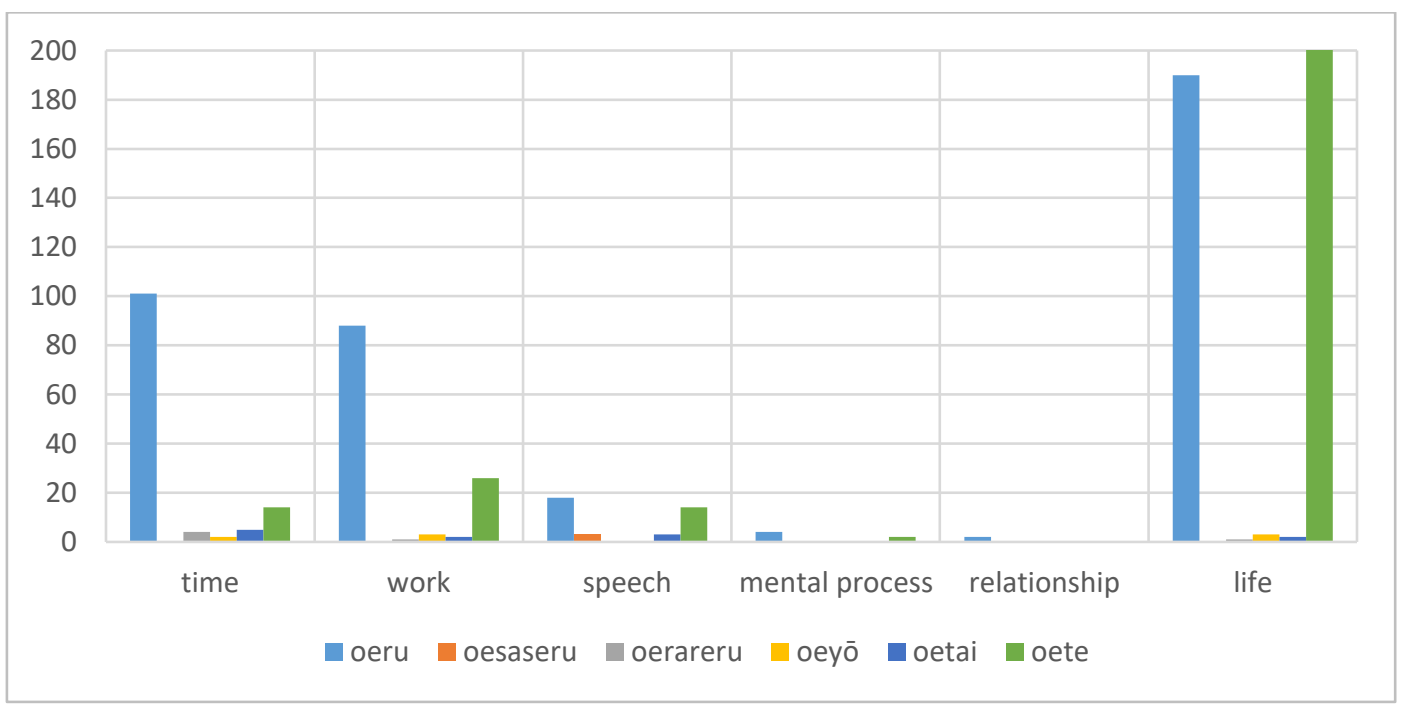

Figure 10: Collocations in relation to verb forms (oeru) 


\section{Conclusion}

The evidence from this research suggests that differences between the use of transitive verbs owaru and oeru exist. The semantical analysis of collocations in combination with the morphological analysis of co-occurring verbs brings forth interesting results. It is however necessary to point out that major issues remain to be solved, despite numerous studies and discussions on verb transitivity.

Section 2 elaborates on verb transitivity with an emphasis on owaru and oeru as a pair. Although it is correct to refer to owaru [intr.] as a verb forming two pairs, one with its transitive counterpart owaru [tr.] and one with oeru [tr.], the analysis presented in Section 3 highlights several inconsistencies in both representation and perception of the verbs.

Firstly, some differences can be discerned in dictionary definitions of the verbs (Section 3.1), particularly regarding the transitivity of oeru. Owaru is listed as an ergative verb in all cases. These results stand out especially when the diachronic change in verb use is taken into consideration. As can be gathered from the comparison of sample sentences from $\mathrm{CHJ}$ and $\mathrm{BCCWJ}$, it is evident that a significate shift in the use of owaru has occurred, despite the consistent dictionary definitions. In modern Japanese, owaru tends to lean towards its intransitive use, while oeru overall appears in a small number of cases (see 3.2).

Furthermore, a similar pattern can be observed in the representation of the verbs within instructional materials, as owaru is most frequently used intransitively. Oeru is rarely seen at all (see 3.3). This also leads to a non-uniform perception of the verbs, as seen in examples gathered from two websites, where users express their doubts regarding owaru and question the correctness of its transitive use (see 3.4).

With these points of concern in mind, the next part of this research deals with the analysis of example sentences gathered from three corpora; BCCWJ, CSJ, and NUCC (Sections 4-8).

Section 5 examines collocations of owaru and oeru and categorizes them into limited semantic fields in order to spot similarities and differences between the verbs. The following Section 6 explains the morphological categories, used to later analyze verb forms in Section 7. Lastly, Section 8 points out structural forms of the verbs in relation to collocations. These analyses bring forth some noteworthy results.

Firstly, owaru has been observed to most often co-occur with collocations classified into the semantic field of 'speech', which is also the largest semantic group found within collocations of owaru. Results also show that causative forms of the verb 'owaraseru' are very common in this semantic field. The high frequency of causative forms, even more so in the corpora of spoken Japanese CSJ/NUCC, is not unexpected. This is partly due to the collocations being classified into the aforementioned semantic 
field of 'speech', which demonstrates a tendency of co-occurring with the frequently used phrase 'owarasete itadaku' (i.e., happyō wo owarasete itadakimasu). A higher number of verb forms expressing desire 'owaritai' has also been observed (i.e., happyō wo owaritai to omoimasu), although not as often as the causative. In some cases, gerundive forms have a higher frequency of appearance, for example in the semantic field of 'work'. Other semantic fields show no particular patterns. When comparing written and spoken Japanese, causative is found in even higher percentages in the latter corpus (CSJ/NUCC).

On the other hand, oeru illustrates a different picture. While the semantic fields overlap with owaru, their distribution differs. Most prominent are the semantic fields of 'life', 'work' and 'time', whereas the largest group within collocations of owaru, 'speech', amounts to only 38 examples for oeru. Similarly, causative is also found in much smaller numbers and is only present in the corpus of spoken Japanese, among verbs co-occurring with collocations semantically classified into the group of 'speech'. Regarding morphological categories of the verb forms, the active oeru and gerundive oete combined cover over $95 \%$ of all forms. That makes the distribution within semantic fields quite uniform and generally split between the two categories.

Another significant result is the correlation of oeru and the past tense. It is often observed in either past form, or within sentences set in the past. This characteristic, along with the high frequency of gerundive forms, which indicate a sequence of actions (one has to end before the other begins), signifies that oeru correlates to the meaning of completion.

Interestingly, both verbs appear almost exclusively in positive forms.

To sum up, it can be concluded that the distribution of semantic fields of collocations for each verb varies heavily. The semantic field of 'speech' covers most of the collocations for the verb owaru, whereas oeru mostly co-occurs with collocations relating to 'life', 'work', and 'time'.

Additionally, it has been observed that compared to owaru, oeru strongly gravitates towards active and gerundive forms as well as past tense, and displays a nuance of 'completion'.

However, it is imperative to admit that the discussion regarding the transitivity of owaru in oeru is still insufficient and in need of further research. To facilitate the understanding and correct the perceiving of verbs, it is necessary to focus on rare cases of ergative verbs during the educational process. This can be done with the help of dictionary definitions, practical examples, and the use of corpora, where special attention is given to owaru as a verb with two transitive pairs; the transitive owaru and oeru. Instructional materials should also provide detailed information, covering all aspects of the two verbs. 
As future research, I propose a questionnaire that focuses on the students' perception of the two verbs. As noted for different languages, this is a topical issue at different levels of $\mathrm{L} 2$ acquisition (Pavlovič, 2020; Ito, 2021, etc.). Comparing the results with this paper could potentially be the next step towards a better understanding of intransitive and transitive verbs and their relations.

\section{Abbreviations}

$\begin{array}{ll}\text { [acc] } & \text { accusative } \\ \text { [adn] } & \text { adnominal use } \\ \text { [caus] } & \text { causative } \\ \text { [cond] } & \text { conditional } \\ \text { [des] } & \text { desire/wish } \\ \text { [ger] } & \text { gerundive } \\ \text { [inf] } & \text { infinitive } \\ \text { [intr] } & \text { intransitive } \\ \text { [neg] } & \text { negation } \\ \text { [nom] } & \text { nominative } \\ \text { [nonpst] } & \text { non-past tense } \\ \text { [pst] } & \text { past tense } \\ \text { [pol] } & \text { polite } \\ \text { [pos] } & \text { positive } \\ \text { [poten] } & \text { potential } \\ \text { [pres] } & \text { present tense } \\ \text { [top] } & \text { topic } \\ \text { [tr] } & \text { transitive } \\ \text { [vol] } & \text { volition }\end{array}$

\section{References}

\section{Books}

Adachi, A. 足立章子, Kurosaki, N. 黒崎典子，\& Nakayama, Y. 中山由佳. (2013). Kanji goi ga yowai anata e 漢字・語菓が弱いあなたへ. Tokyo: Bonjinsha.

Amano, M. 天野みどり，Ōshima， M. 大島資生， Sugimoto, T. 杉本武, Numata, Y. 沼田善子， Masuoka, T. 益岡隆志, \& Yazawa, M. 矢澤真人. (2013). Wākubukku nihon bunpō ワーク ブック日本文法. Tokyo: Ōfū.

Bekeš, A. (2005). Pregled slovnice japonskega jezika [Lecture notes]. Ljubljana: Faculty of Arts, Department of Asian and African studies. 
Hmeljak Sangawa, K., Kobayashi, R., Kumagai, Y., Shigemori Bučar, C., Maeno, Y., \& Shukuri, Y. (2007). Uvod v japonsko pisavo: hiragana, katakana in prvih 854 pismenk. Ljubljana:

Faculty of Arts, Department of Asian and African studies.

Hmeljak Sangawa, K., Ichimiya, Y., Ida, N., Kawashima, T., Koga, M., Moritoki Škof, N., \& Ryu, H. (2012). Japonščina za začetnike 1. Ljubljana: Ljubljana University Press, Faculty of Arts.

Hmeljak Sangawa, K., Ichimiya, Y., Ida, N., Kawashima, T., Koga, M., Moritoki Škof, N., \& Ryu, H. (2012). Japonščina Za Začetnike 2. Ljubljana: Ljubljana University Press, Faculty of Arts.

Hmeljak Sangawa, K., Ichimiya, Y., Ida, N., Kawashima, T., Koga, M., Moritoki Škof, N., \& Ryu, H. (2016). Japonščina Za Začetnike 2. Ljubljana: Ljubljana University Press, Faculty of Arts.

Ito, H. (2021). From Native-speaker Likeness to Self-representation in Language: Views from the Acquisition of Japanese Transitive and Intransitive Verbs. Acta Linguistica Asiatica, 11(1), 25-36. https://doi.org/10.4312/ala.11.1.25-36

Izuhara, S. (2010). Q\&A-7 'owaru' wa tadōshi? Q\&A-7 「おわる」は他動詞? Nihongo kyōshi Izuhara Shōji webusaito 日本語教師＼cjkstart泉原省二ウェブサイトRetrieved from http://blog.livedoor.jp/s_izuha/archives/1924977.html

Kokuritsu kokugo kenkyūjo 国立国語研究所. (2003). Bunrui goihyō: zōho kaitei-ban 分類語 彙表: 増補改訂版(Word list by semantic principles, revised and enlarged edition). http://doi.org/10.15084/00002282

Makino, A., et al. (Eds.). (1998). Minna no nihongo shokyū 2 honsatsu みんなの日本語 : 初級 II : 本冊. Tokyo: Surīē nettowāku.

Makino, A., et al. (Eds.). (2013). Minna no nihongo shokyū 2 honsatsu みんなの日本語 : 初級 II : 本冊. Tokyo: Surīē nettowāku.

Morita, Y. 森田良行. (1994). Dōshi no imironteki bunpō kenkyū 動詞の意味論的文法研究. Tokyo: Meiji Shoin.

Numata, Y. 沼田善子. (1989). Nihongo dōshi jita no imiteki taiō (1): tagigo ni okeru taiō no ketsuraku kara 日本語動詞 自・他の意味的対応（1）：多義語における対応の欠落 から (Semantic Correspondence between Transitive and Intransitive Verbs in Japanese (1): Correspondence Gaps in the Case of Polysemy). Kenkyū hōkoku-shū 研究報告集, 10, 193-215. http://doi.org/10.15084/00001122

Oka, M., Tsutsui, M., Kondo, J., Emori, S., Hanai, Y., \& Ishikawa, S. (2009). Jōkyū e no tobira: kontentsu to maruchimedia de manabu nihongo 上級へのとびら：コンテンツとマル チメディアで学ぶ日本語(Tobira: Gateway to Advanced Japanese Learning through Content and Multimedia: Textbook). Tokyo: Kuroshio shuppan.

Okutsu, K. 奥津敬一郎. (1967). Jidōka tadōka oyobi ryōkyokuka tenkei - jitadōshi no taiō [自 動化・他動化および両極化転形--自・他動詞対応. Kokugogaku 国語学, 70, 46-66.

Pavlovič, M. (2020). Grammar Errors by Slovenian Learners of Japanese: Corpus Analysis of Writings on Beginner and Intermediate Levels. Acta Linguistica Asiatica, 10(1), 87-104. https://doi.org/10.4312/ala.10.1.87-104

Shigemori Bučar, C. (2008). Causative and Politeness. Asian and African Studies, 12(3), 71-82.

Srdanović, I. (2016). Kolokacije in kolokacije na daljavo v japonskem jeziku: korpusni pristop. Ljubljana: Scientific Research Institute of the Faculty of Arts.

Tanimori, M, \& Sato, E. (2012). Essential Japanese Grammar a Comprehensive Guide to Contemporary Usage. Tokyo: Tuttle. 


\section{Dictionaries}

Hmeljak Sangawa, K. (2006). 終える. In Japonsko-slovenski slovar JaSlo. Retrieved from http://nl.ijs.si/jaslo/cgi/jaslo.pl.

Hmeljak Sangawa, K. (2006). 終わる. In Japonsko-slovenski slovar JaSlo. Retrieved from http://nl.ijs.si/jaslo/cgi/jaslo.pl.

Kondō, I. 近藤いね子, \& Takano, F. 高野フミ (Eds.). (1993). Oeru. In Shogakukan Progressive Japanese-English Dictionary. Tokyo: Shōgakukan.

Kondō, I. 近藤いね子, \& Takano, F. 高野フミ (Eds.). (1993). Owaru. In Shogakukan Progressive Japanese-English Dictionary. Tokyo: Shōgakukan.

Nishio, M. 西尾実, Iwabuchi, E. 岩淵悦太郎, \& Mizutani, S. 水谷静夫 (Eds.). (1955). 終える. In Kokugo jiten 国語辞典. Tokyo: Iwanami shoten.

Nishio, M. 西尾実, Iwabuchi, E. 岩淵悦太郎, \& Mizutani, S. 水谷静夫 (Eds.). (1955). 終わる. In Kokugo jiten 国語辞典. Tokyo: Iwanami shoten.

Masuda, Ko. 増田綱 (Ed.). (1998). Oeru. In Kenkyusha's New Japanese-English Dictionary. Tokyo: Kenkyūsha

Masuda, Ko. 増田綱 (Ed.). (1998). Owaru. In Kenkyusha's New Japanese-English Dictionary. Tokyo: Kenkyūsha

Matsumura, A. 松村明 (Ed.). (2006). 終える. In Daijirin 大辞林. Tokyo: Sanseidō. Retrieved from https://kotobank.jp/.

Matsumura, A. 松村明 (Ed.). (2006). 終わる. In Daijirin 大辞林. Tokyo: Sanseidō. Retrieved from https://kotobank.jp/.

Shinmura, I. 新村出 (Ed.). (1955). 終える. In Kōjien 広辞苑. Tokyo: Iwanami shoten.

Shinmura, I. 新村出 (Ed.). (1955). 終わる. In Kōjien 広辞苑. Tokyo: Iwanami shoten.

Yamada, T. 山田忠雄, Shibata, T. 柴田武, Sakai, K. 酒井憲二, Kuramochi, Y. 倉持保男, Yamada, A. 山田明雄, Uwano, Z. 上野善道, Ijima, M. 井島正博, \& Sasahara, H. 笹原宏 之 (Eds.). (2012). 終える. In Shin meikai kokugo jiten 新明解国語辞典. Tokyo: Sanseidō.

Yamada, T. 山田忠雄, Shibata, T. 柴田武, Sakai, K. 酒井憲二, Kuramochi, Y. 倉持保男, Yamada, A. 山田明雄, Uwano, Z. 上野善道, Ijima, M. 井島正博, \& Sasahara, H. 笹原宏 之 (Eds.). (2012). 終わる. In Shin meikai kokugo jiten 新明解国語辞典. Tokyo: Sanseidō.

\section{Corpora}

Fujimura, I., Chiba, S., \& Ōso, M. (2012). Lexical and grammatical features of spoken and written Japanese in contrast: Exploring a lexical profiling approach to comparing spoken and written corpora. Proceedings of the VIIth GSCP International Conference: Speech and Corpora, 393-98.

Kokuritsu kokugo kenkyūjo 国立国語研究所. (2019). Gendai nihongo kakikotoba kinkō kōpasu 現代日本語書き言葉均衡コーパス (Balanced Corpus of Contemporary Written Japanese - BCCWJ). Available online at https://chunagon.ninjal.ac.jp/. 
Kokuritsu kokugo kenkyūjo 国立国語研究所. (2019). Nihongo hanashikotoba kōpasu 日本語 話し言葉コーパス (Corpus of Spontaneous Japanese - CSJ). Available online at https://chunagon.ninjal.ac.jp/.

Kokuritsu kokugo kenkyūjo 国立国語研究所. (2019). Nihongo rekishi kōpasu 日本語歴史コ ーパス (Corpus of Historical Japanese - CHJ). Available online at https://chunagon.ninjal.ac.jp/. 